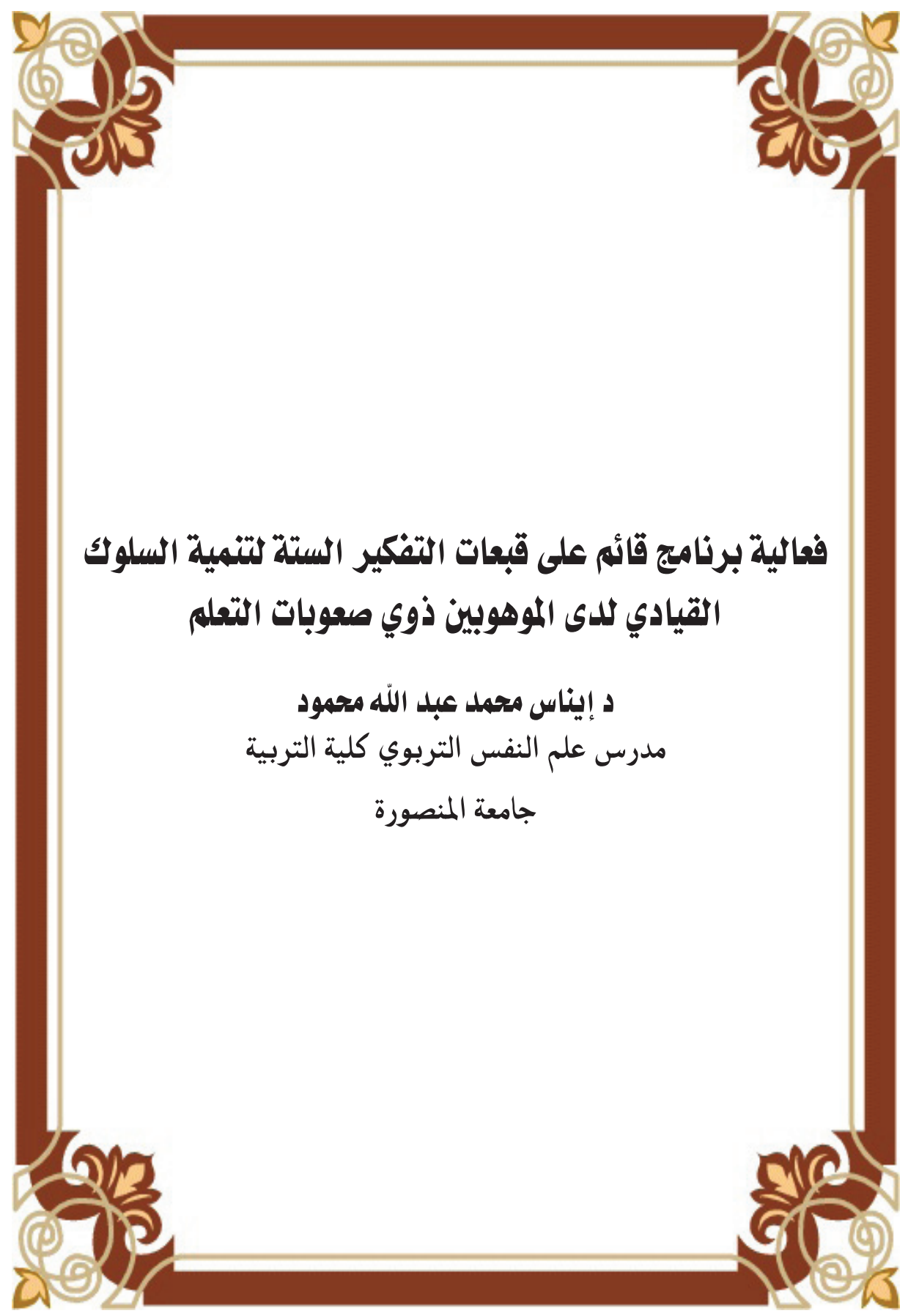



إنتـا نحيـا اليومِِّ عالم لا يسـع إلا الأقوياء النابهين، ولا يعترف بالضـعفاء

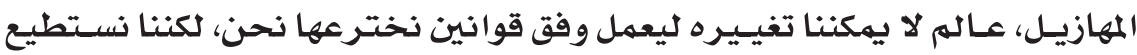

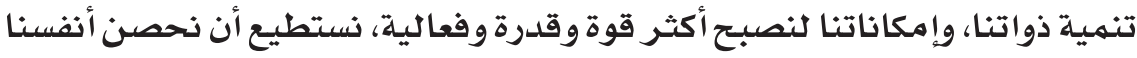
بـدرع مـن المهارات الفعالة، التي توفر لنا مسـاحة كبيرة من الحماية، ونحن نصسعد

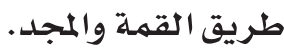

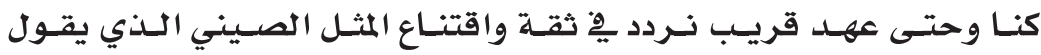

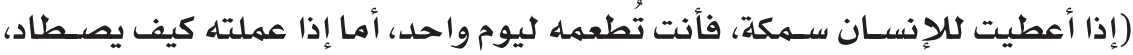

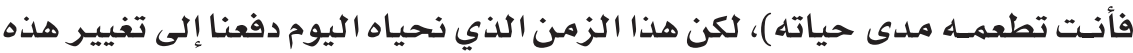

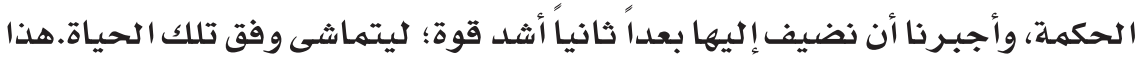

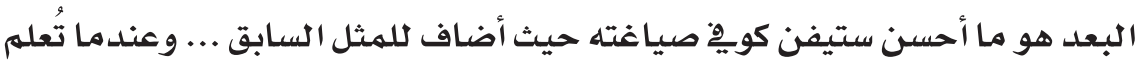

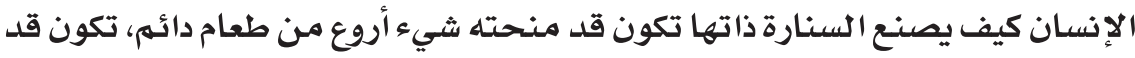

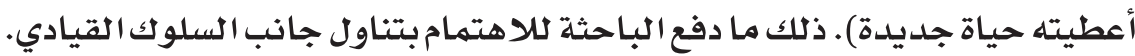

الموهوبـون والمتفوقـون هـم الـثروة الحقيقيـة لأي مجتمـع، والرصـيد

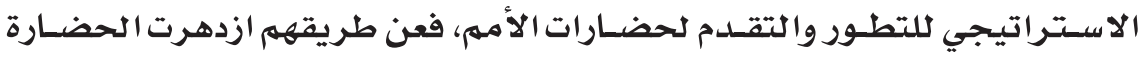

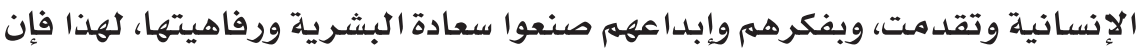

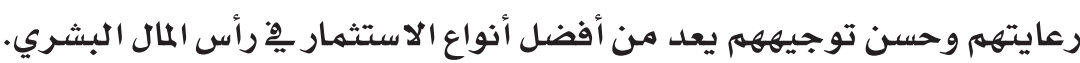

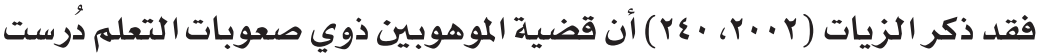

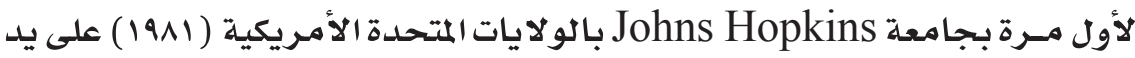

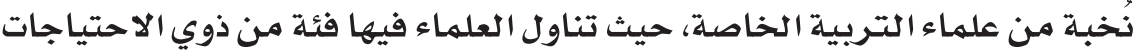

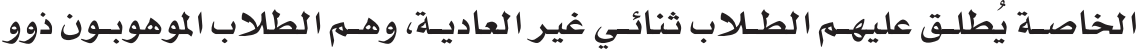

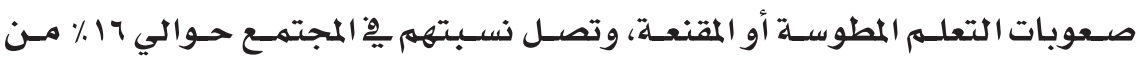

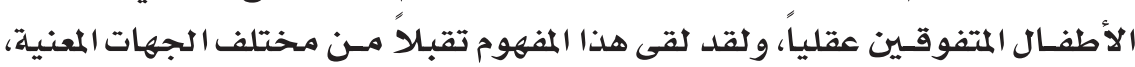

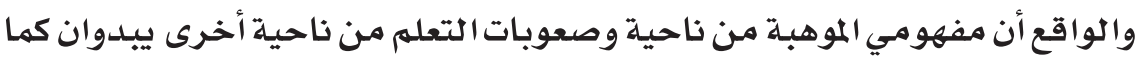

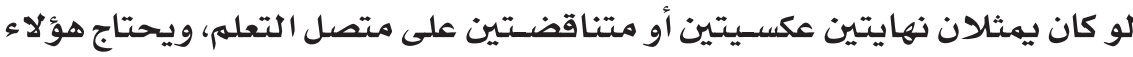

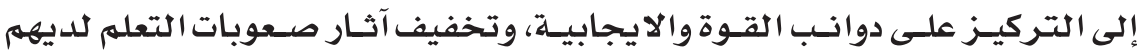


ففـي ظل الانفجار المعلوماتي الذي يشـهـده العالم اليوم، ومـع التقدم المعربِ

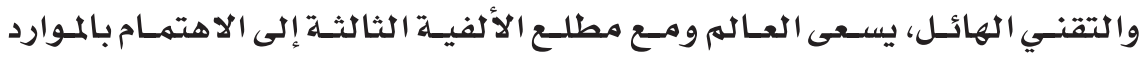

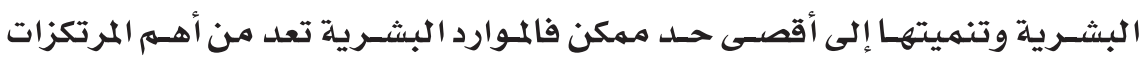

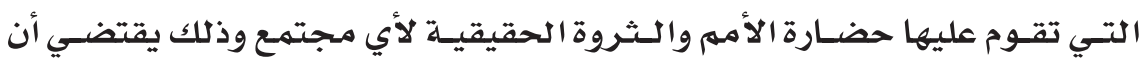
يعد الإنسـان عدته لمواجهة كل التحديات من خلال وضـــع الخطط المبـيـية على أسس علمية لمواكبة هذا التقدم يِّ عالهم التعليهم والتدريس والعمل على تهكين الطلاب هن مواكبة مسـتجدات العصـر واسـتيعابها من خلال التصـــي للتغيرات المتسـارعة بها يحقق التنمية الشـاملة والتي تعد اسـتراتيجيات القبعات السـت من أهم مـرتكزا تها ومن خلالها يتم تحسين بعض مهارات القيادة.

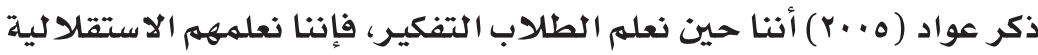
والتحـرر مـن الاعتمــاد علـى الآخريـن، وأن يكونـوا مفكريـن واثقين مـن قدراتهم

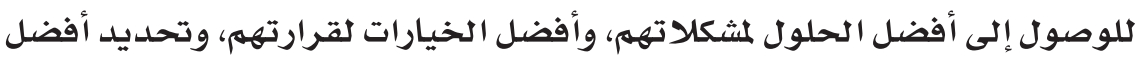

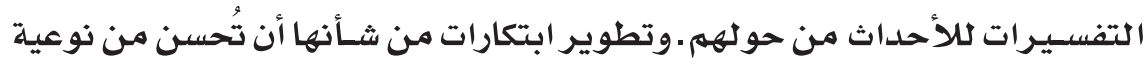
حياتهم وحياة الآخرين.

وهنـاك فرقـاً بــين تعليهم التفكيـر وتعليـهم مهـارات التفكير .فتعليـم التفكير يتضهن الفرص والمواقف وتنظيم الخبـرات التي تتيح الفرصة أمام الطلبـة للتفكير ودفعهم ومبادراتهم على استغلال توظيف العمليات الذهنية المختلفة بها، أما تعليم مهارات التفكير فيتضمن افتراض أن التفكير مثله مثل أي مهارة قابلة للتعلهم والنقل والتوظيف فِ مرحلة حياتية أو أكاديهية جديدة، ويتضمن تعلم مهارة التفكير تعله

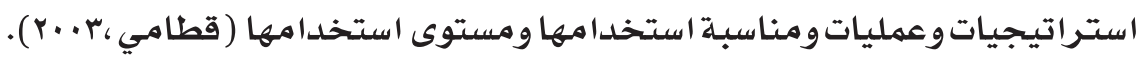

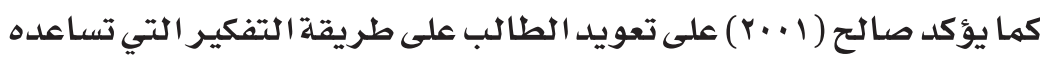
على النظــرة الموضـوعيـة إلى مشـاكل الحيـاة، وبالتالي العمـل على إزالــة المعتقدات الفاسدة والآراء السابقة، والتعصب الأعمى، والتخلص من أساليب التفكير الخرايِ

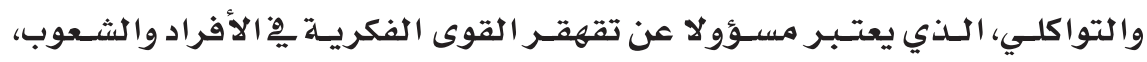

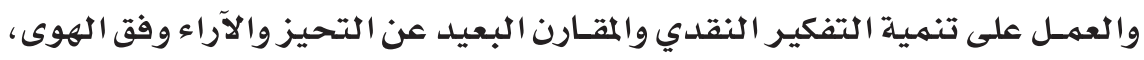
وأن ينظر الطالب إلى حل مشكلات الحياة اليومية نظرة موضوعية ،كي يتمكن من التغلب عليها نتيجة التفكير السليه. 


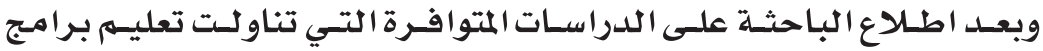

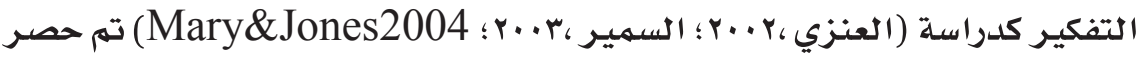
مجموعة من المزايا التي يهكن أن تحققها برامج تعليم التفكير والتي من أهمها : تطوير القدرات الإبلداعية الكامنـة لدى الطلبة.

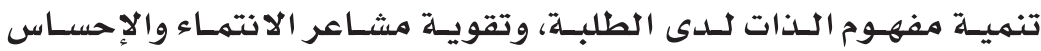

بالمسؤو لية نحو المجتهـع

التعرف على المواقف والمشكلات الحياتية المتوقعة.

مساعدة الطلبة ِيخا الانتقال من مرحلة اكتساب المعرفة إلى مرحلة توظيفها

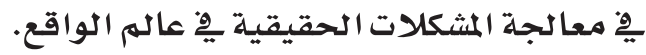
إكساب الطلبة القدرة على حل المشكلات واتخاذ القرار.

وبفحص الباحثة لتلك المزايا السابق ذكرها استتتجت ان تلك المزايا تصب فِ تعلهم مهارات السلوك القيادي والتي ترغب الباحثة يِّنتهيته لإيهانها بأن القادة هم ثروة يهتلكها المجتمـع فهم يقومون بـور الفاعل فِ تحديد قدرة الأغلبية على الفعل ويفجـرون طاقـات، وينجحــون يْ تفعيلها بشـكل إيجابي لنخرج جيـلا من القيادات الرائعة كلأمـة.

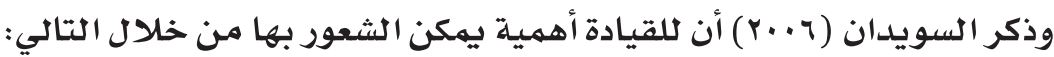
السيطرة على مشكلات العمل ورسم الخطط اللازمة للتعامل معها. إعادة التوازن للحياة أي وضـع الشخص المناسب يِّ المكان المناسب.

$$
\text { مواكبة التغيـرات المحيطة. }
$$

وضـع استراتيجية ناضجة يِّة عملية تحرك محفزة نحو هدف سام.

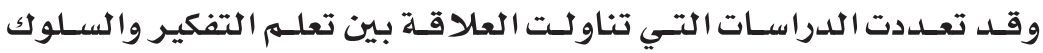
القيـادي، فقد درس الســويدان، والعدلـوني (ع . . ا أن القدرة على التفكير من أبرز الصــفات التـي يتصـف بهـا القائد، فمن صــفات القائــــ الفاعل القدرة علـى التحكم بالنفس والتفكير بصـورة واضحة، كما يحدد سـتيوارت (Stuart,2003) أن الذكاء والتحصيل العالي من السمات المتفق عليها عند القائد الجيد. . وطبق العنزي (Y . . . م)

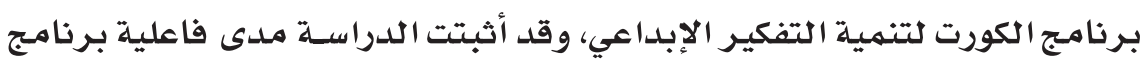
التفكير يج تنمية المهارات القيادية. 
ولقد تعلدد البـرامج العالمية لتعليم التفكير ومهارات، فعلى سبيل المثال هناك برنامسـ البنـاء العقلـي لجيلفورد الذي يسـتهدف تطوير المهارات المعرفية للتفكير، وكذلـك برنامــج فلسـفة لبهـان كلأطفال الـذي يـركز علـى التفكير كموضـوع قائم

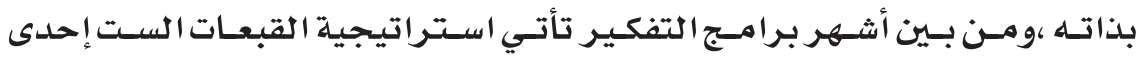
الاسـتراتيجيـات التـي طرحها الطبيـب المالطي إدوارد حول تنميـة عمليات التفكير،

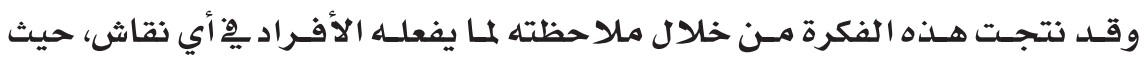

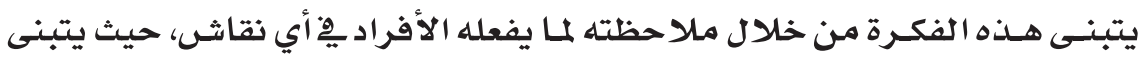

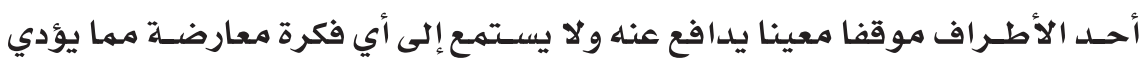

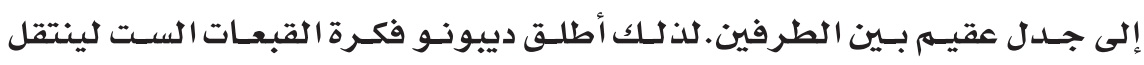
بالتفكير بعيدا عن الجدل إلثة نوع جديد من التفكير يسـهى بالتفكير الموازي الذي يوفـر بـدائـل عملية أو تطبيقية، بحيث يعمل على تشــيع التعاون بين كافة الأفراد

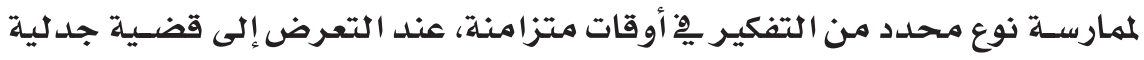

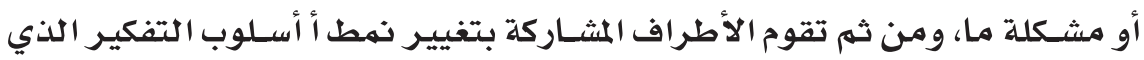

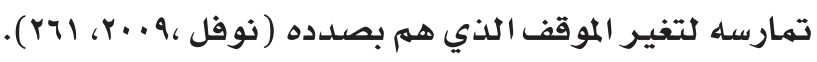

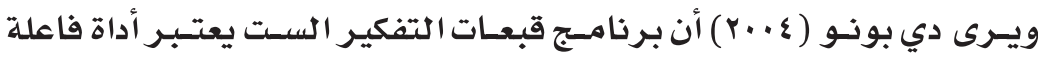
لتتظيـه عملية التفكير، وتغيير الطرق التقليدية التي يفكر فيها الأثسخاص أثناء اتخاذ القرارات وحل المشكلات.

فترى الباحثـة أن تعليـمه مهارات التفكيـر هو بهثابة تزويد الفـرد بالأدوات التي يحتاجها حتى يتمكن من التعامل بفاعلية مـع أي نوع من المعلو مات أو المتغيرات. فيقول نبي الله صلى الله عليه وسله (إنها العلهم بالتعله والحلهم بالتحله). وأيضـاً اهتمت الباحثة باسـتراتيجيات القبعات السـت التي تعترف بالمشاعر كجزء مهم للتفكير، والتي تعد أحد برامـج التفكير الحديثة التي تسـتهدف توضسيح وتبسـيط التفكير وزيـادة فعاليته، وتدريـب المتعلهم لتغيير نهط تفكيره، فالقبعات السـت عبارة عن وسـيلة توضـح الحالة الذهنية للفرد يِ لحظة معينة بشـكل رمزي وني

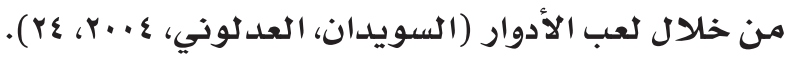


ويعد موضوع التفكير والسلوك القيادي من الموضو عات المترابطة والمتداخلة، لوجـود علاقـة بــين القدرة على التفكيـر وتحســين المهارات القياديـة، ولذلك ذكر (Janet \& Kronborg, 2000)

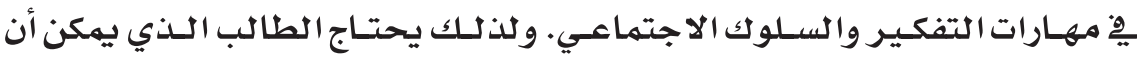

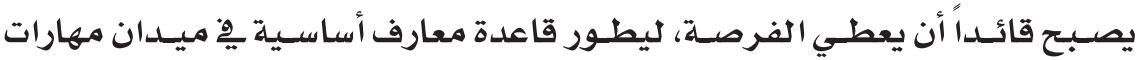
التفكير، والقدرة على حل المثكلات، والتفكير الابداعي.

ويؤكسد المختصـون أن هنـاك فجـوة، تتفاوت يِّ درجة اتسـاعها بـين ما يبديه

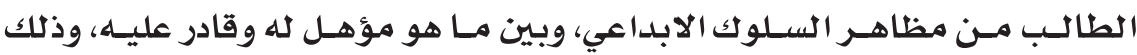

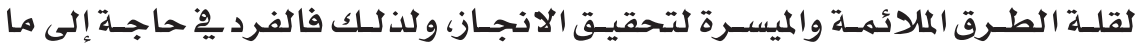
يحفظ إبدا عه، ويوظفه عن طريق التدريب. كما أكدت السرور (r... r. أن كثيرا من الدراسـات التي طبقت البـرامـج الخاصسة بهـهارات التفكير، أسفرت نتائجها أن تعليه التفكير يؤثر بشـكل موجب على كثير من النواحي، مثل تنمية تقدير ذات إيجابية، وتنمية القدرة على التفكير التباعدي، وتحسين الإنجاز الأكاديهي.

كما يرى دي بونو ( 1 . . أن برا مـج التفكير و منها برنامـج القبعات الست تتيح

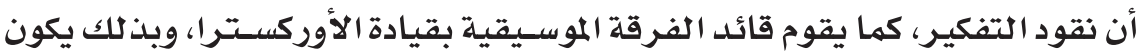
بالاســطاعة أن ننتقل إلى مسـارات متعددة، ونفكر بطرق مختلفة حول مشـكلة ما،

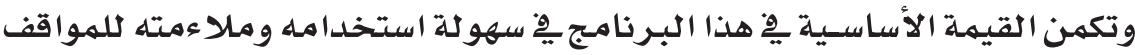
التعليمية المختلفة، ويتضـــن برنامج قبعات التفكير السـت، السلوك القيادي، الذي يظهـر واضـحاً يِّ تفكير القبعـة الزرقاء، فالـذي يلبس القبعـة الزرقاء يقـوم بـور قيادي يِ المجموعة من حيث توجيه أفراد المجموعة إلى نوع التفكير المستخدم. وقد وجلت Stuart, (2003) أن برنامج قبعات التفكير السـت ينهي أنهاط القيـادة المختلفـة فطبيعـة البـرنامـج تسـتند على حل المشـكالات والتفكيـر الإبـاعـاعي

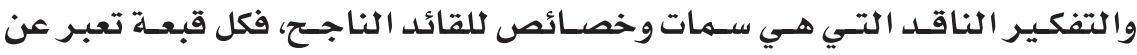
طريقة تفكير معينة، وتركز القبعة الزرقاء على السـلوك القيادي. ومن هذ المنطلق تم اختيار السلوك القيادي وربطه بقبعات التفكير الست. 
وتعـد دراســة الباحثـة من الدراسـات التجريبية التـي يتهم فيها بنـاء برنامـج

تدريبـي وتعليهـي، يشـــل تدريـب الطلبـة على اسـتخدام مهـارات ذهنيـة بفاعليـة وبطريقة مختلفة مها يستخدمه الطالب يِ ظروف الصف العادي، ويهكن أن ترجع

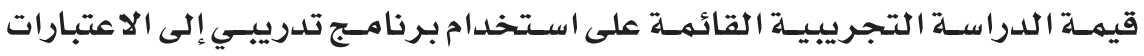
التتظيمية الصفية، والمحتوى، وما يتضمن من اهتمام المدربة بها يوفره من تنظيم تدريبـي، ونشـاطات، وتغذية راجعة فورية التي يهر بها جــراء ما ينتج من أفكار يتم تعديلها، وتغييرها ،وإثرائها من زملائه أو من المعلم فور ظهور الاستجابة.

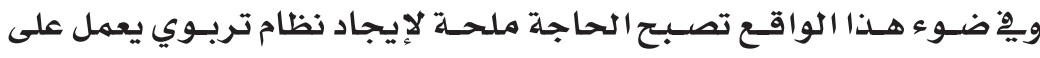

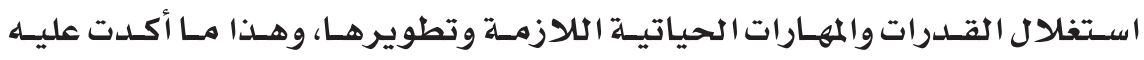
المؤتهـرات التربويـة، التـي ركـزت على ضــرورة تطوير أنـواع التفكيـر المختلفة التي

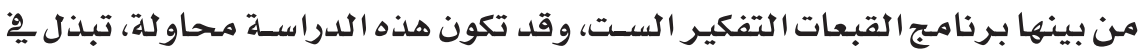
مجال تطوير التفكير والمهارات القيادية حيث ستقدم هذه الدراسة بيانات تجريبية عن فاعلية برنامج قبعات التفكير السـت يِّ تعليم التفكير وتنمية المهارات القيادية، وتفسـح المجال للطلبة كي يفكروا تفكير إبداعياً، مها يجعل عند الطلبـة قدرة عالية مِ التعامل مـع مواقف الحياة المستقبلية.

كمـا اهتمــت الباحثـة بالتطبيق على عينة هـي من فئسة ذوي الإعاقة بل ولها طابع آخر أنها ذات الاستثناء المزدوج وهم فئة الموهوبين ذوي عيدي صعوبات التعلم.

\section{مشكالة البحثث:}

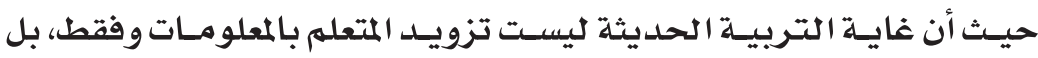
ومسـاعدته على تنهيلة تفكيره العلهي وتزويده بعقليـة مرنة تهكنه مـن فهم البيئة

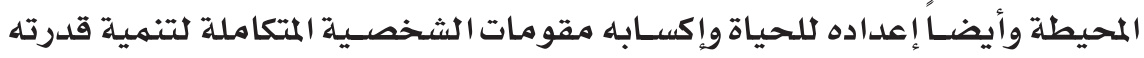
على التفكيـر السـليهم وحل المشـكلات والاعتمـاد على النفسـ فمن من المؤسـف أن كثيراً من طلبة الثانوية غير ملمهين تماماً بهمارات التفكير، ومعظم هؤلاء الطلبة ليس لديهم القدرة على حل المشكلات، واتخاذ القرار أو حتى الإدرالك والفهم الجيد، ومثل هؤلاء الطلاب هم سيوف المستقبل والعقل المدبر والمدير لمشكلاته. 
فالغرض من هذه الدراسـة هو تطوير برنامـج تفكير قائم على قبعات التفكير الست لدى دي بونو، وقياس أثره يْ تنمية السلوك القيادي لدى الطلاب الموهوبين من ذوي صـعوبات التعلم من المرحلة الثانوية .حيث لاحظت الباحثة أن هناك اتسـاع مِّْ الفجوة بين ما نقو له أو نكتبه على الورق حول ما نمارسـه يِّا الغرف الصفية وكان من الضروري تقديم البيئة المناسبـة التي تجعل الطالب يشعر بالمسئولية والمشاركة

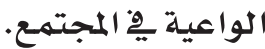

فلـم تعـــ الطرائق التـريويـة القائمهة على أسـاليب الحفظ والتلقين وحشـو

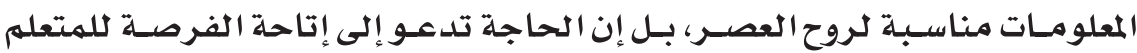

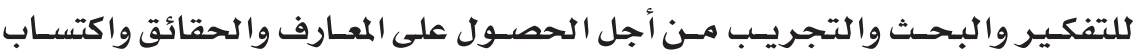

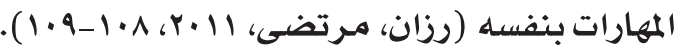

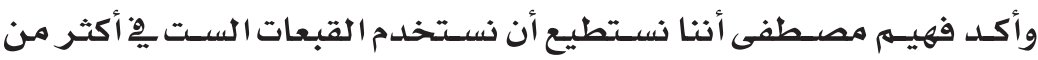

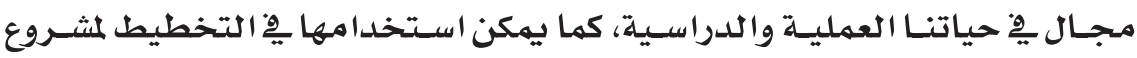
معين، أو صنـع القرار، أو البحث عن حلول مناسبة للمشكلات التي تعترض طريقنا

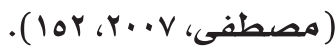

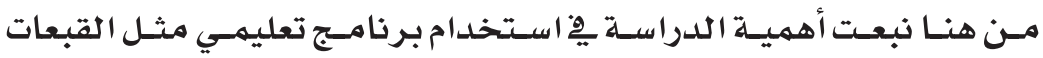
التفكيـر السـتة لتتميـة السـلوك القيـادي لـدى طـلاب المرحلـة الثانويـة (محسل الدراسـة) لأهمية تلك المرحلة كما ذكر أريكسـون بأنها فترة البحث عن الذاتواتلتي

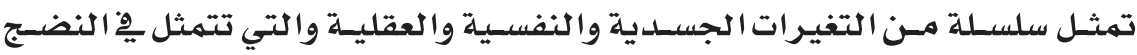

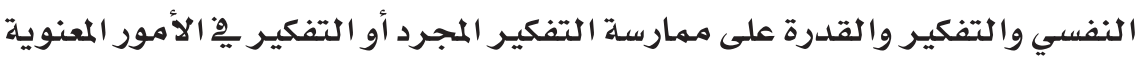

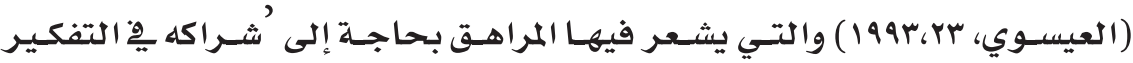

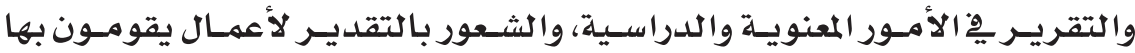
واحترام خصوصياتهم.

وتتحد مشكلة البحث في السؤال التالي :

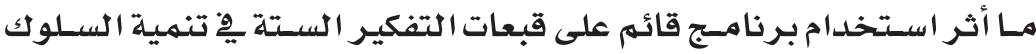
القيادي لدى الموهوبين ذوي صعوبات التعلم من طلاب المرحلة الثانوية ؟ 


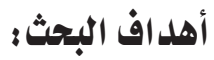 \\ يهدف البحث إلى ما يلي:}

بناء برنامج تدريبي قائم على قبعات التفكير الست لتنمية السلوك القيادي

لدى الموهوبين ذوي صعوبات التعلم من طلاب المرحلة فئلة الثانوية.

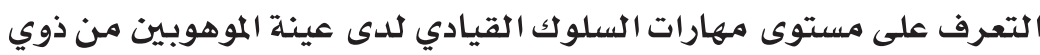

صعوبات التعلم من طلاب المرحلة الثانوية.

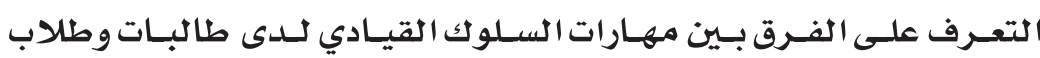

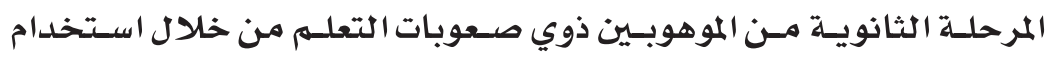

بر بامجج القبعات الست للتفكير.

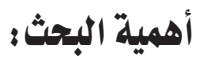

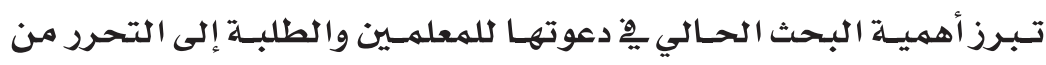

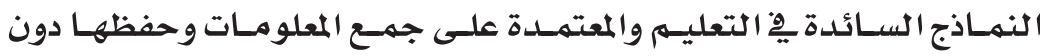

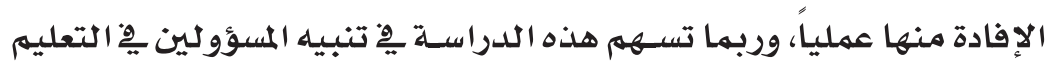

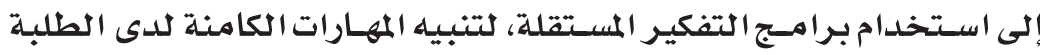

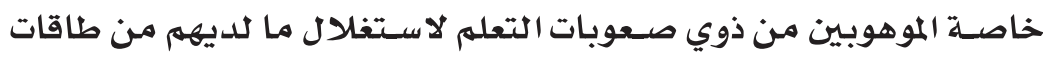
وإمكانيات و الإفادة منها لتنمية مهارات مثل السلوك دوبات القيادي لديهم.

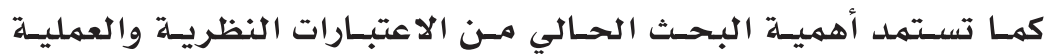

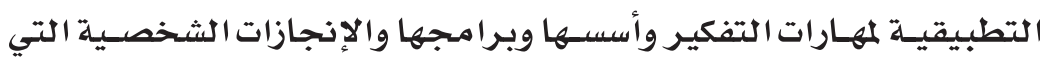
يمكن أن يحققها الطلاب من التدريب على هذه الممارسات، وتتحد التهد الأهمية النظرية للدراسة الحالية بالآتي:

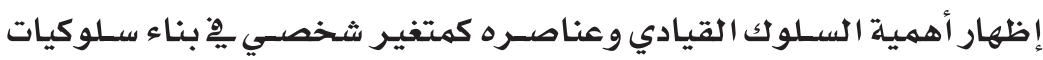

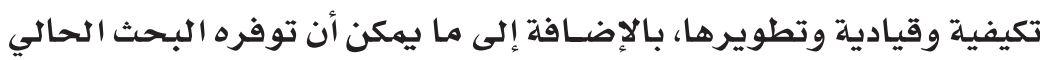

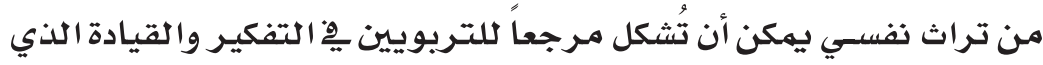
يُبنى عليه النشاط والحيوية.

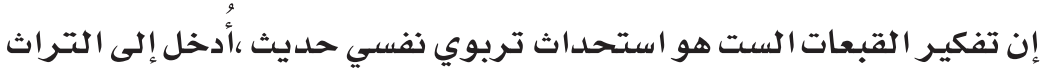

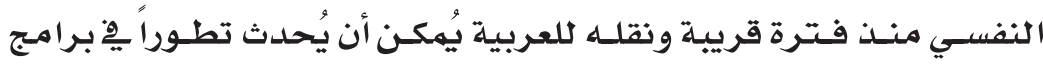
تعليه وتعلم التفكير للطلبة يِّ أي بلد. 
قد تسـاعد هذه الدراسـة يِّ إكسـاب التلا ميذ الثقة بالنفس وتعويدهم تقبل نقــ الآخرين، وكيفية نقد ذا تهمه، وحل مشـكلاتهمه. لذنـك تأمل الباحثة أن تكون هذه الدراسـة بمثابة إثراء إلى الأدب التربويوي.

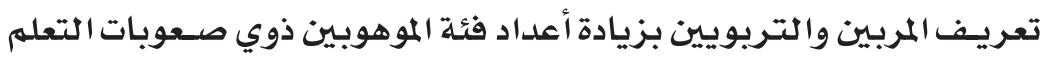

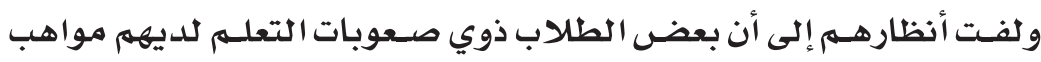

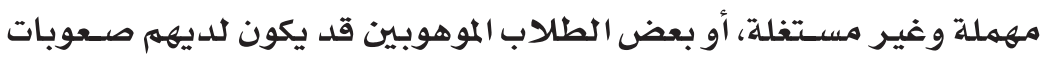

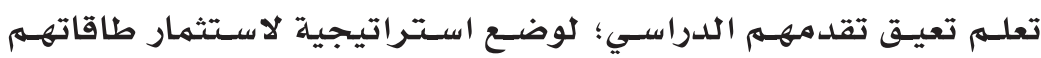
وقدراتهم.

\section{ويمكن أن تُددد الأمميـة التطبيقيـة بالنقاط الآتيـة :}

يُهكن أن يسهم البحث الحالي بها تزوده من برنامج تدريبي لتفكير القبعات

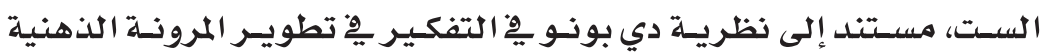

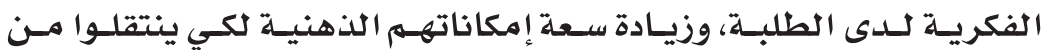

$$
\text { إجراءات تفكير إلى إجراءات تفكير أخرى . }
$$

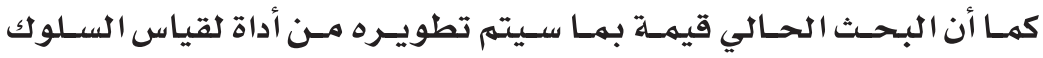

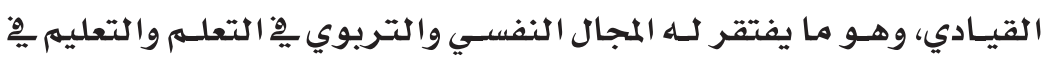

$$
\text { مـرحلة المراهقة. }
$$

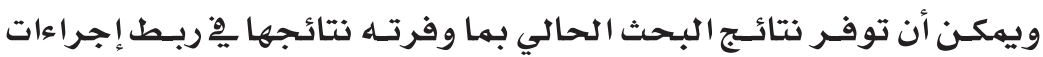
التفكير وفـق بر نامسج دي بونو، والسـلوك القيـادي وربطه بتوجهـات بحثية

$$
\text { واستدخال ذلك بِ الممارسات التربوية. }
$$

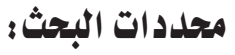

المدددات البشـريـة : يتحدد البحث الحالي بالعينـة المسـتخدمـة فيها وهي من

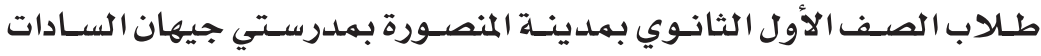

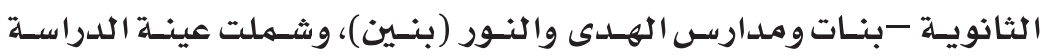

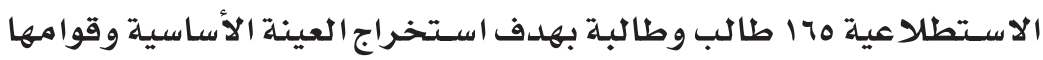
Tr من الطالاب مقسمـين بالتساوي إلى مجموعتين ضابطة وتجريبية. (ب) المدددات مكانية :تم التشـخيص بملدرسـي جيهان السـادات والهدى والنور بمدينة المنصورة التابعة لمحافظة الدقهلية. 


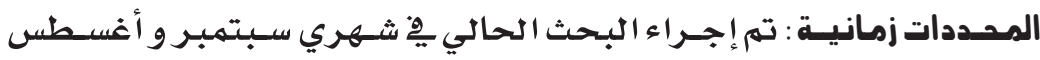

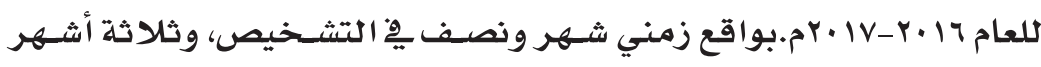

$$
\text { ونصف لتطبيق البـرنامـج المستخدم. }
$$

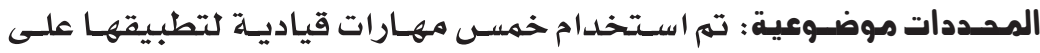
العينـة المســتهدفة من خلال البـرنامجروهم (مهارة التخطيط، مهارة اتخاذ

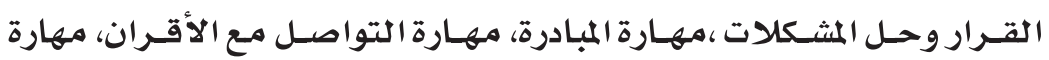
تحمل المسئولية) .

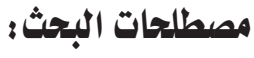

البرنـامي: : يُعرف البرنامـج بأنه : مـجموعة الخبـرات التعليمية المتكاملة والمصممة

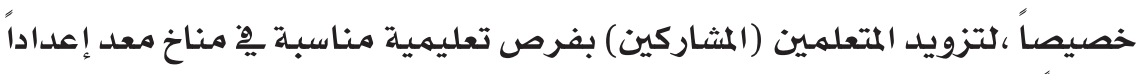

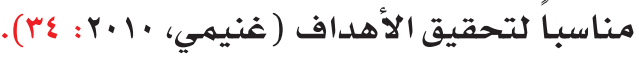

إسـتراتيجية قبعـات التفكـير السـت :The Six Thinking Hats Strategy : هـو أحسد برامـج تعليهم التفكير الحديثة وضـعه الطبيب البـريطـاني إدوارد دي بونو

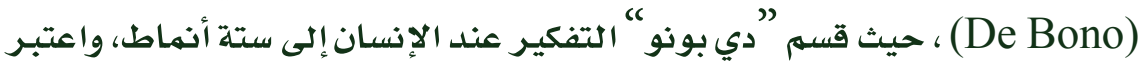
كل نهـط كقبعـة خياليـة يلبسـها الإنسـان أو يخلعها حسب طريقة تفكيره يخ تلك ولك اللحظة، بحيث ينتقل الفرد بتفكيره من أسلوب معين إلى أسلوب آخر حسب الموقف

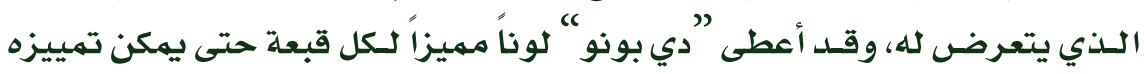

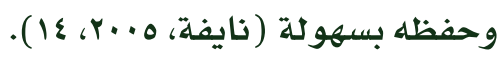

مــارات القيـادة :Leadership Skills: هـي المهارات التـي يتــدرب عليها طلاب

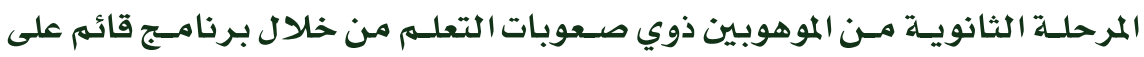
اسـتراتيجية قبعات التفكير السـت والتي تسـاعدهم على تحسين السـلوك القيادي

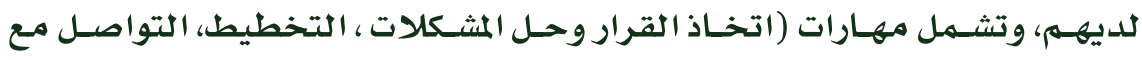
الأقران، تحمل المسئولية، المبادرة).

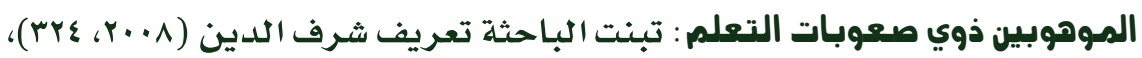
حيث يعرفهم بأنهم "هؤلاء الطلاب الذين تكبح صعوبات تعلمهمم النوعية الأصلية 
(الأكاديهية - النهائية ) أو المصاحبـة لتوظيف إمكانات الموهبـة لديهم، وهي مـا تعوق تحقيق إمكانات هذه الثروة الإنسانية، وتحويلها إلى واقع فعلي مستثمر، مها يهدر

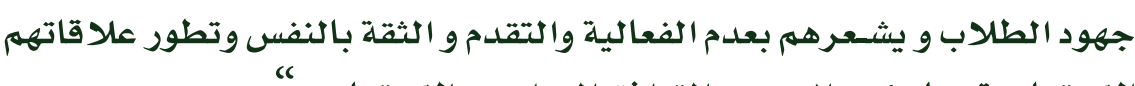
الاجتماعية بها يؤدي إلى سوء التوافق الدراسي والاجتماعي

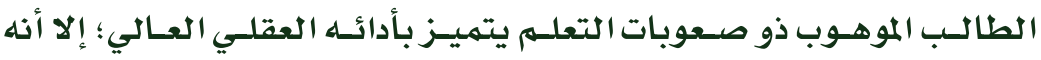
يعاني من قصـور أكاديهي معين قد يصـاحبه قصـور فِ المعالجة الذهنية التنفيذية Executive processing deficit

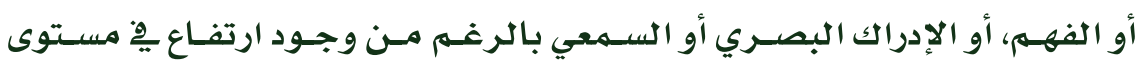
الأداء العقلي العهاء العباء

وتقصــ الباحثـة بالموهوبـين يف العينـة هــم الطلاب الذين يظهـرون موهبـة

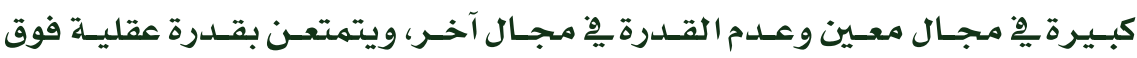

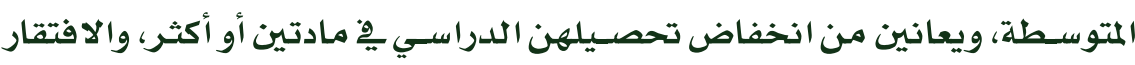

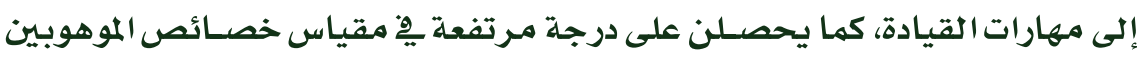
ذوي صعوبات التعلم.

تشفيص الموموبين ذوي صعوبات التعلم : أشار (Swanson(1999) إلى أن هناك ثلاثة محكات يتم يِ ضوئها التعرف على أولئك التلا ميذ الموهوبين ذوي صعوبات التعلم وتحديلدهم وهي:

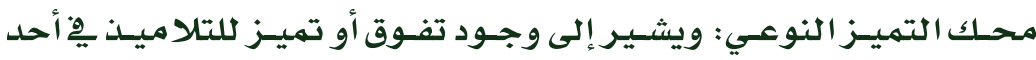

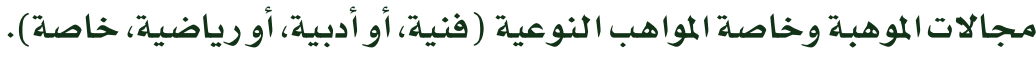

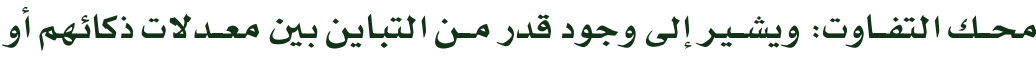

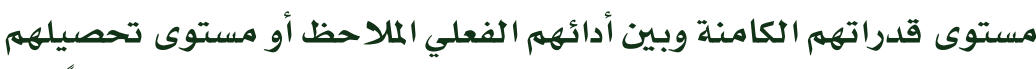

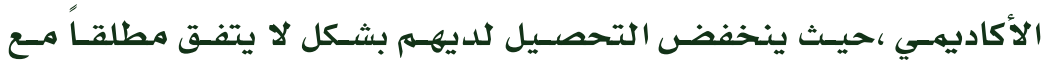
نسبـة ذكائهم.

محكك الاسـتبعاد: ويشـيـر إلى إمكانية تهييز الموهوبين ذوي صـعوبات التعلهم عن ذوي الإعاقات، أو ذوي صـعوبات التعلهم الأخرى، ومن ثم اسـتبعادهم عن

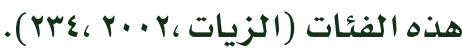


فيشـهد عصـرنا الحالي ثـورة ِِّا التقدم العلمـي والتكنو لوجي له يسـبق لها

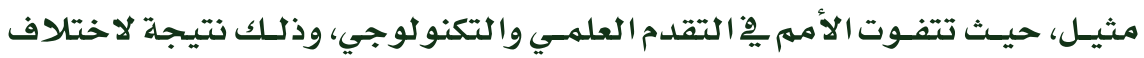

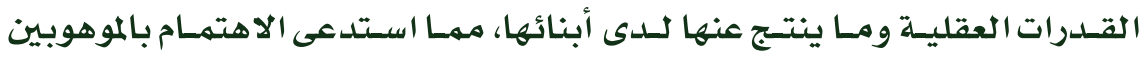

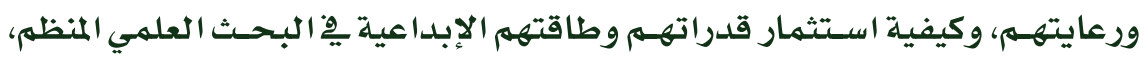

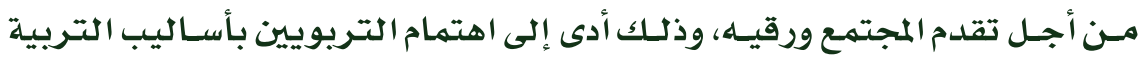

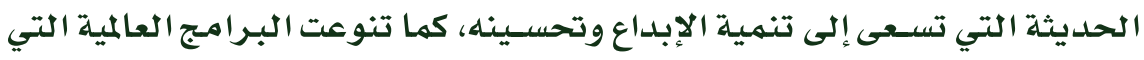
تهدف إلى تنمية التفكير بأنواعه المختلفة، ومن أشهر برامج تعليه التفكير برنامج

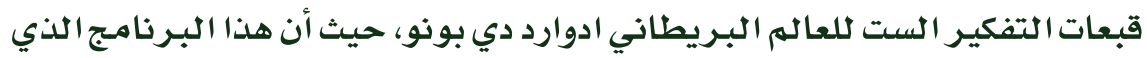

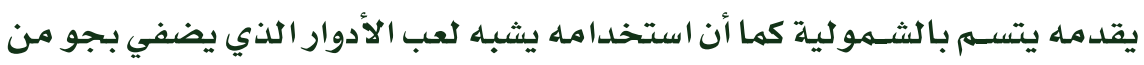
السرور والمتعة على التلا ميذ ويزيد من دافعيتهم للتعلهم وتحسين التفكير.

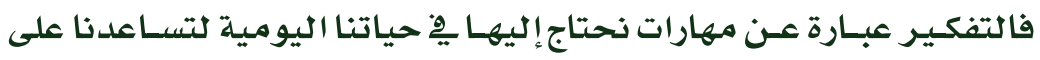

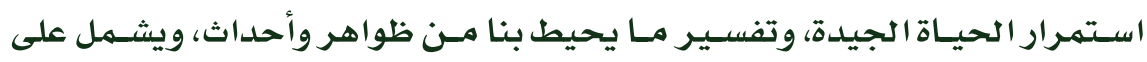

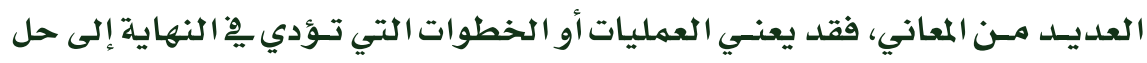

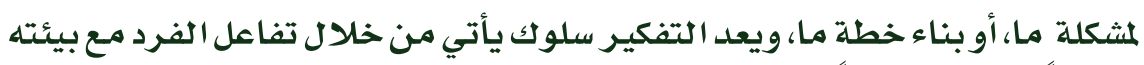

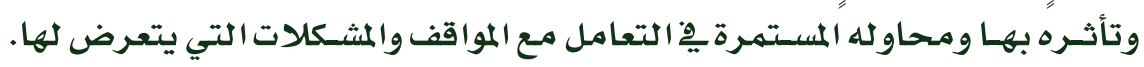

\section{تعريف التفكير : تمبر}

قد تعددت تعريفات التفكير وومنها:

التفكـيـر هـو ذلك الشـيء الـــي يحـدث أثنـاء حل المشـكلة، وهو الـــي يجعل للحيـاة معنــى، أي هـو عمليـة واعية يقوم بهـا الفرد عن وعـي وإدراك و لكنها

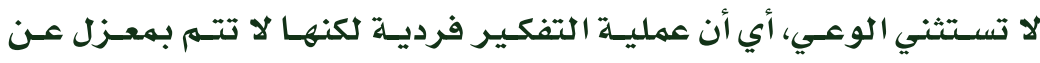
البيئة المحيطة، بل تتأثر بالسـياق الاجتماعي والسياق الثقايِّا الذي تتم فيه

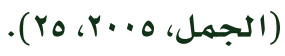

ويفترض دي بونو أن التفكير مهارة عملية يُمارس بها الذكاء نشاطه اعتماداً

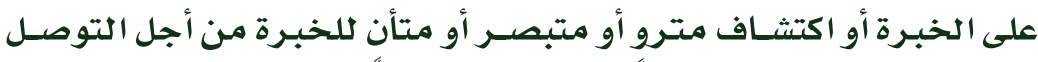

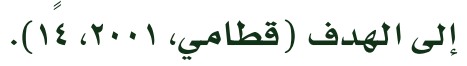

ويرى مصــفى أن التفكير هو عمليات النشـاط العقلي التي يقوم بها الفرد من أجل الحصول على حلول دائمة أو مؤقتة لمشكلة ما، وهو عملية مستمـرة 
ِِِ الذهـن لا تتوقف أو تنتهـي مـا دام الإِنسـان يِ حالـة يقظـة، و هـو أرقىى العمليات العقلية والنفسـية التي تهيز الإنسان عن غيره من الكائنات الحية

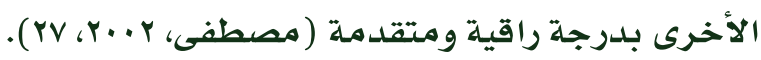

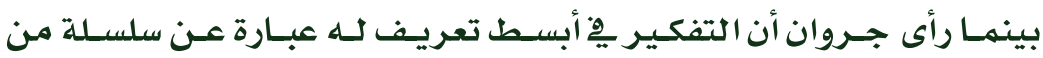
النشـاطات العقليـة التي يقوم بها الد ماغ عند ما يتعرض المثير يتم اسـتقبـاله

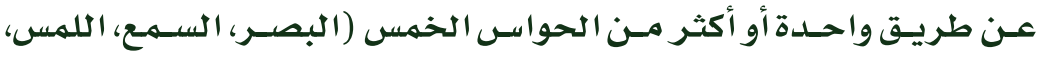

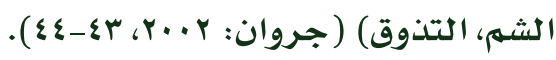

واسـتنتجت الباحثة من تعدد التعريفات السـابقة أنـه لا يوجد تعريف واحد

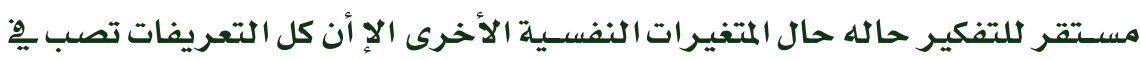
نفس البوتقة ولذلك تعرف الباحثة التفكير بأنه : نشاط عقلي يقوم به الفرد عندما يواجـه مواقـف مـا يحتاج إلى تفسـير للوصـول إلى الحـل المثالي من خـلال تنظيهم خبـراتـه بطريقة جديلدة، وتتضـهـن عمليـة التفكير مهارات وخطـوات متعددة يقوم بتطبيقها ليتوصل إلى حل للموقف الغامض، وقد يقوم بتقويم هذا الحل وتعميمه على المواقف والمثكلات الأخرى المتشابهة.

\section{مبررات تعليم التفكير :}

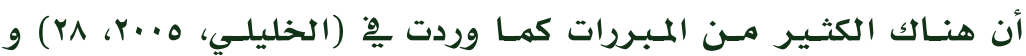

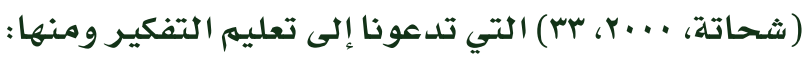

تعقـد المجتمعـات الحلديثة التي ظهر فيها الحاجة للتفكير بطرق جديدة لم

تعد العادات والتقاليد والطرق القديهة كافية لحلها.

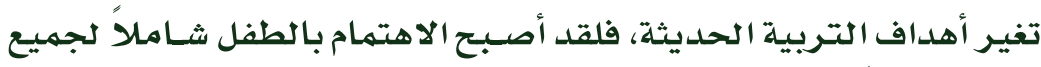

النواحي بلدلا من الاهتمام بجانب واحد وهو الجانب المعريف.

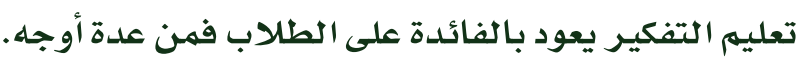

التفكير ضـرورة حيوية للإيهان واكتشـافات نواميس الحيـاة و إعمال العقل

والتفكير والتدبر يِّلق الله والتبصـر بحقائق الوجود الذي عظهها الدين

$$
\text { الإسلا مي. }
$$

دور التفكير يِّانجــاح الدراسـي والحياتي فتعلم مهـارات التفكير قد يكون

أهم عمل يمكن أن يقوم بـ المعلم. 
يِّ القـرن الحـادي والعشـرين يتعاظـم الرجــوع إلى الأسـاسـيات والتي تتعلق

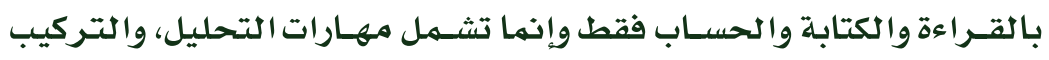

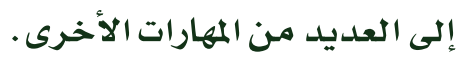
لا بـ من تعليم الطلبة أسلوب التعلم بأنفسهم، وهذا مبدأ مهمم لأنه يعتد مِيخ أساسه على مهارسة التفكير بفاعلية. أن التدريـب على التفكير يعتبـر محورا أسـاسـيا لاسـتيعاب وفهـهم كل المواد المعرفية التي يتفاعل معها الطالب يِ المدرسة.

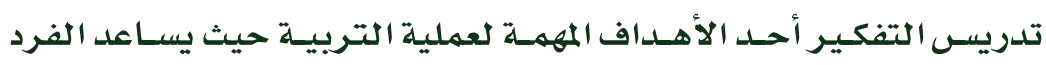

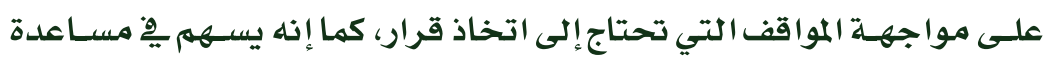
التلالميذ ملواجهة صعوبات التعلم حتى يصبـحوا مفكرين جيدين. وترى الباحثة نظراً للتغيـرات السـريعة والمسـتمرة يِّ عصرنا الحالي ضـرورة

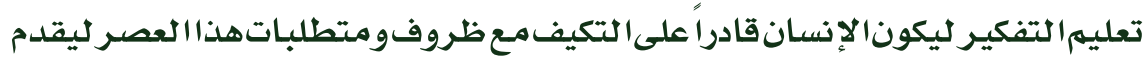

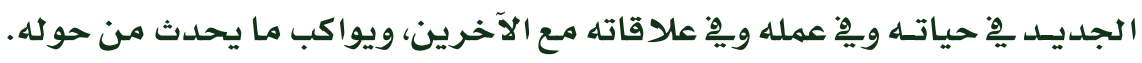
ومها سـبق عرضــه يتضـح للباحثة أنه قد أصبـح هدف تنهيلة مهارات التفكير

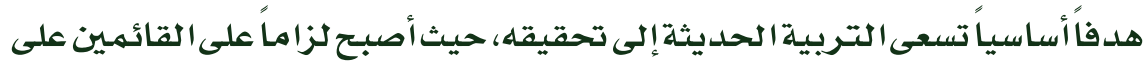
العملية التعليمية أن يهتموا بتعليهم الطلبة مهارات التفكير المتنو عة وتنميتها لديهم.

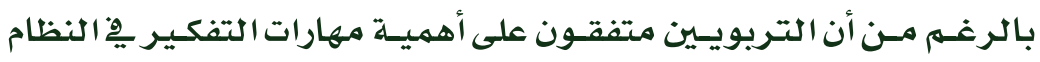
التعليمسي، إلا أنـه لا يوجد اتفاق مؤكد بينهم على الكيفية لتتهية تلك المهارات، فقد

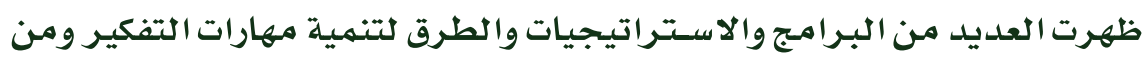

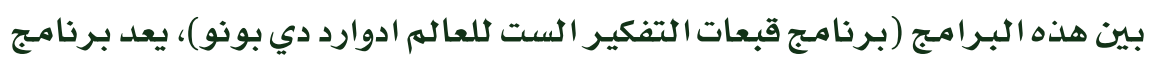
قبعات التفكير الست من برامج تعليه التفكير التي تهدف إلى تبسيط عملية التفكير

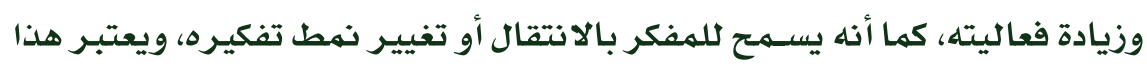
البـرنامـج نهوذج متكامل لتحقيق التفكير المتوازي.

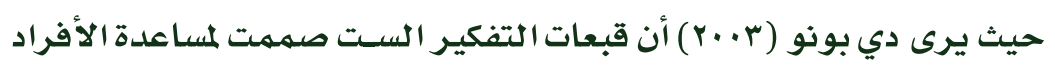

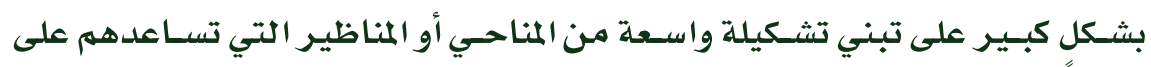

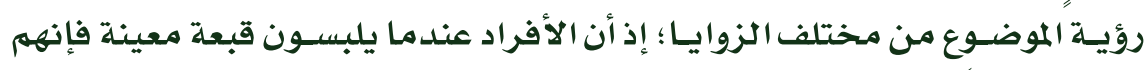

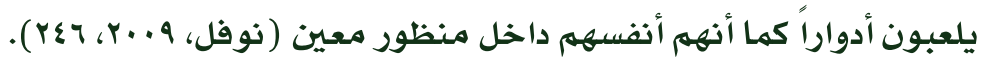




\section{تعريف برنـامج قبعات التفكير الست :}

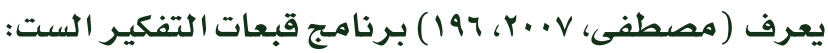

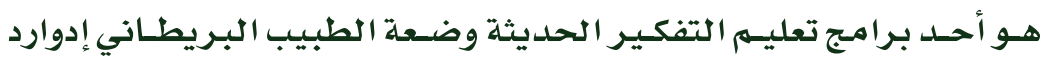

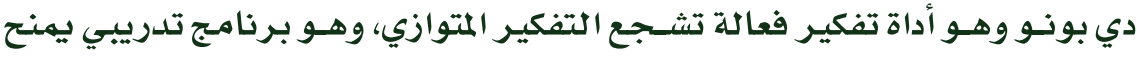

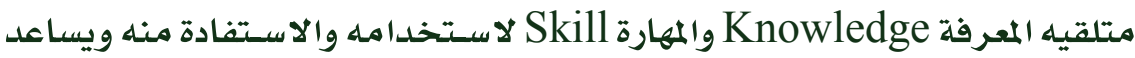

$$
\text { على الإبداع وتطوير قدرات الفرد. }
$$

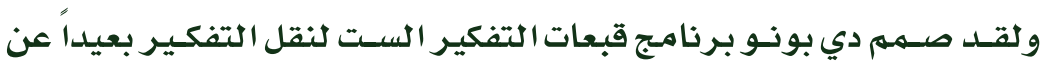

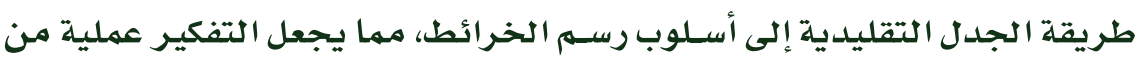

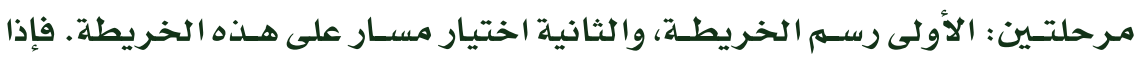

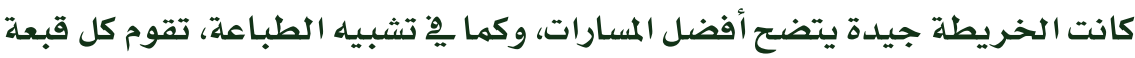

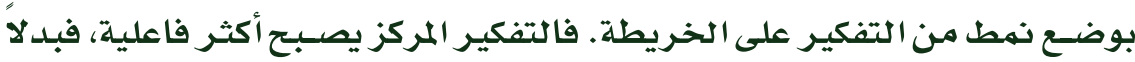

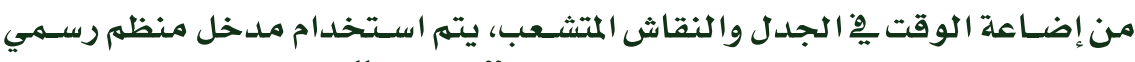

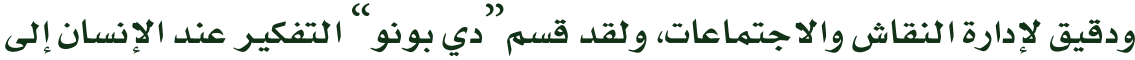

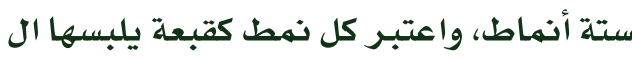

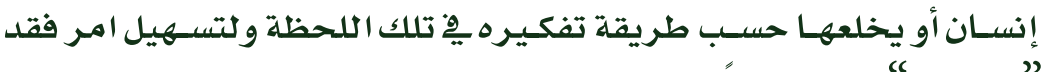
أعطى ”دي بونو" لوناء مميزاً لكل قبعة حتى يمكن تمييزه وحفظه بسهوهولة. طرق التفكير التي تمثلما قبعات التفكير الست: هنالك طرق مختلفة للتفكير تمثلها قبعات التفكير الست كما ذكرها دي بونو وهي:

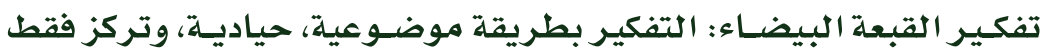
على الحقائق الموضوعية والأرقام.

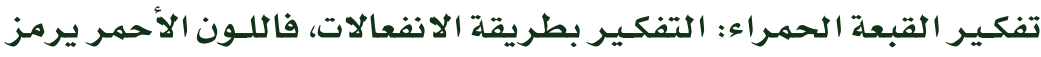

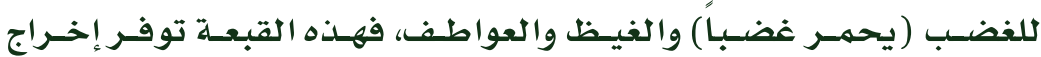
(العواطف، المشاعر، والحدس). تفكير القبعة السوداء: التفكير بطريقة تشاؤمية ناقدة، وهو تفكير الفير منطقي

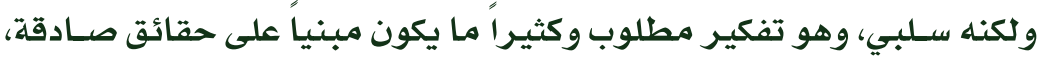

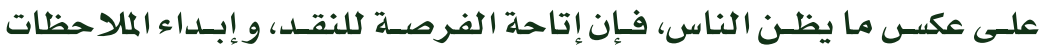

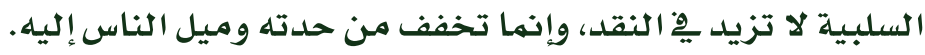


تفكير القبعة الصـفراء: هو التفكير الإيجابي الذي يركز على الإيجابيات

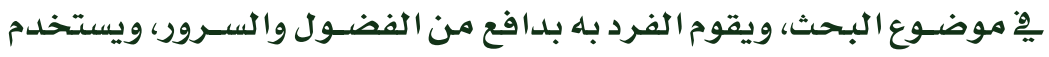

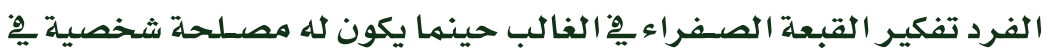

تفكير القبعـة الخضــراء: التفكـير هنـا يكـون بطريقــة إبداعيـة، فالقبعـة الخضــراء تعنــي النهــو والتغيـيـر والخروج عـن المألـوف، فهي رهـز للابتكار والإبداع والأفكار الجديدة. تفكير القبعــة الزرقـاء: تفكير القبعة الزرقـاء يعني تفكير التحكـم يِّأنواع التفكيـر الأخـرى (التفكير حول التفكيـر)، فهو بهثابة لوحسة تحكم كبيرة،

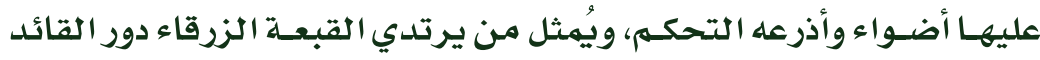
لجلســة الحـوار والتفكير، مهمتـه ضـبط عمليـات التفكير وتوجيهطـا فهو يحمـي المجموعـة مـن الانـزلاق او الابتعـاد عـن الموضـوع الـذي يـــور حوله البحث أو التفكير.

ويرى دي بونو ان اختيار القبعات الست قد تم على الأسـاس الآتي:

أن القبعـات هـي الأقرب إلى رأس الإنسـان، والرأس يحوي الدماغاغ الذي يقوم بوظيفة التفكير، لذلك القبعات هي الأقرب إلى التفكير.

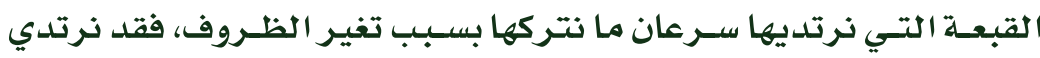

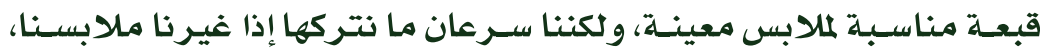
وهكذا الأفكار فقد نُعجب بفكرة ما يِّ وقت معين، ونتخلى عنها بعد ذلك.

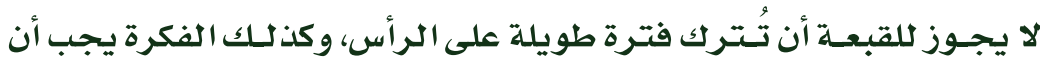

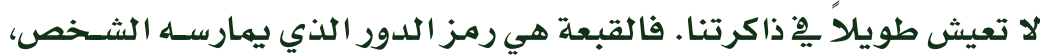
فالشرطي يرتدي قبعة مهيزة، والقاضي يرتدي قبعة خاصـة... وهكذا.

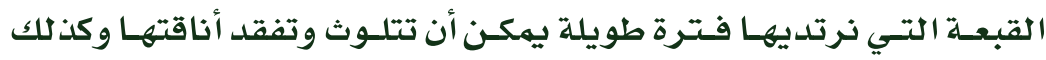

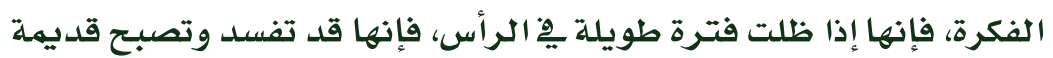

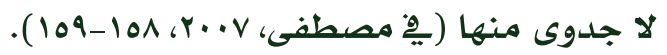


وترى الباحثة أنه تم اختيار القبعات للأسباب التالية:

لارتباط القبعة بالرأس منطقة العقل والتفكير.

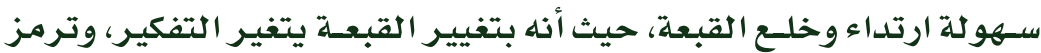

القبعة إلى الدور الذي يقوم به التلميذ يِّ تلك اللحظة.

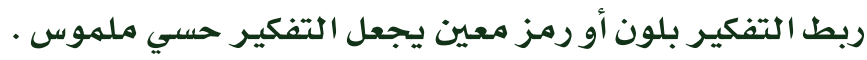

\section{كيفية استفدام قبعات التفكير الست :}

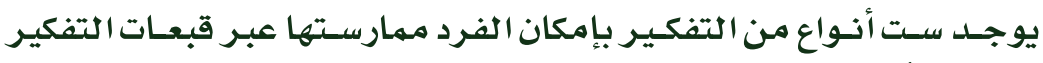

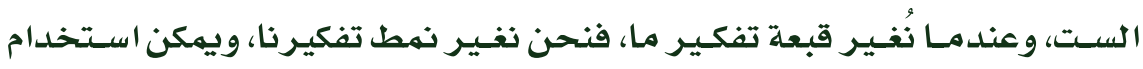

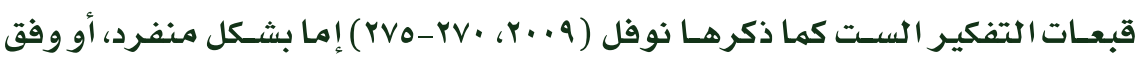

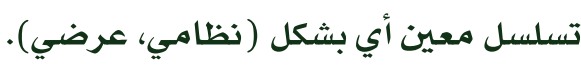

الاستفدام الأول : الاستخدام العرضي لقبعات التفكير الست : ويكون ذلك عند استخدام

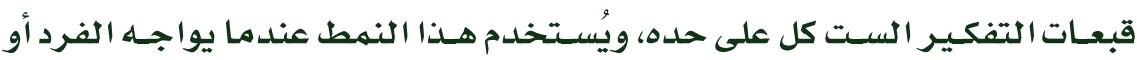

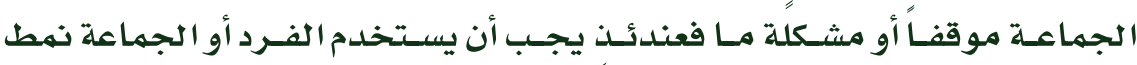

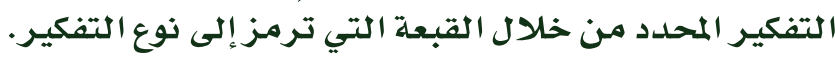

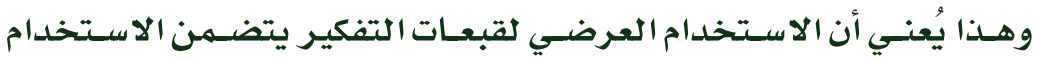

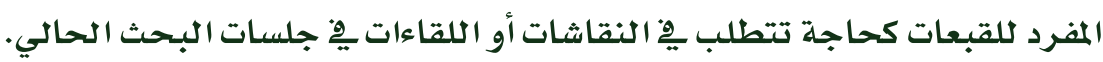

الاســفدام الثاني :الاسـتفدام النظامي لقبعات التفكير السـت : يُعني هذا الاسـتخدام

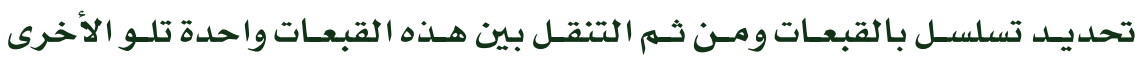

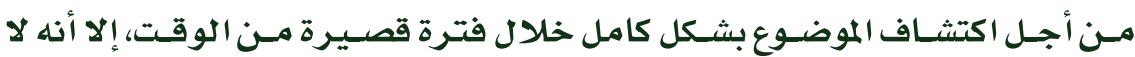

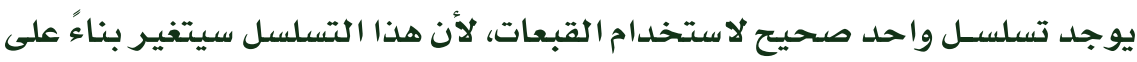

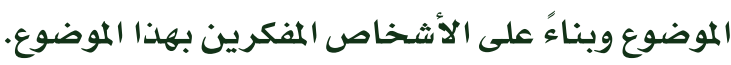

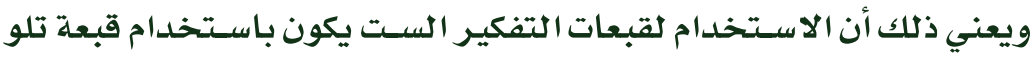

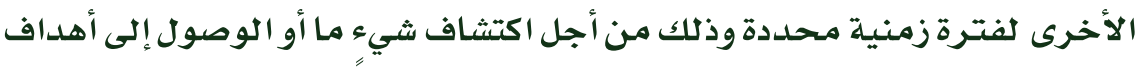

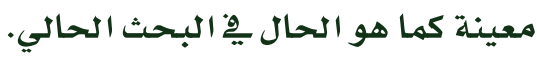




\section{مديزات قبعات التفكير الست :}

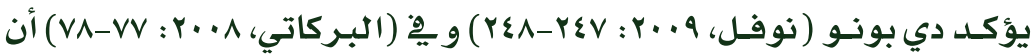

قبعات التفكير الست تعمل على تحقيق مجموعة من المنافع، منها:

توجه الانتباه نحو مناح متعددة للقضية أو المشكلة، وبالتالي يدرك الفرد أن

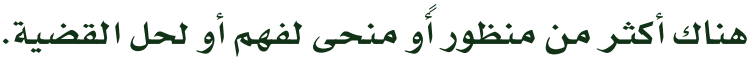

تحسن من عملية التواصل بين الأفراد المثاركين.

تحسن من عملية اتخاذ القرار لدى الأفراد.

تنمية التفكير التعاوني بين المشاركين، ومـراقبة الأنا.

تخلق التفكير المتوازي من خلالال الأفراد.

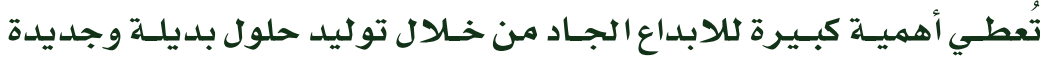

للهشكلات المطروحة.

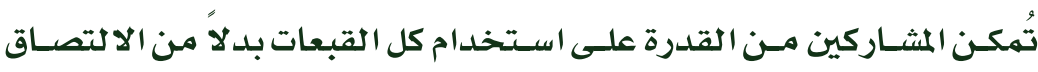

بنمط واحد من التفكير فقط.

تساعد المشاركين على مهارسلة التقييم الذاتي لأنفسهم.

أسلوب سهل مهكن استخدا مـه مـع الصغار والكبـار.

ومن هنا جاء اختيار الباحثة لبـرنامج القبعات التفكير السـت دون غيره هن

$$
\text { البـرامج لأسباب الآتية : ومنياء }
$$

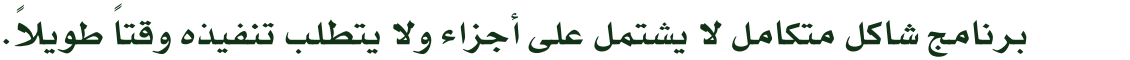

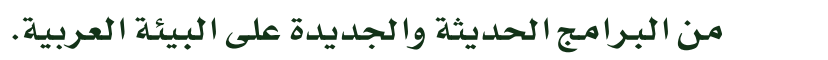
邓 邓 هن السهولة التعرف على القبعات الست لخلوه من التعقيد.

\section{القيادة والسلوك القيادي:}

لقـلد خلـق الله سـبـحانه وتعـالى الإنسـان وكر مـه علـى جميـع مخلوقاته بأن

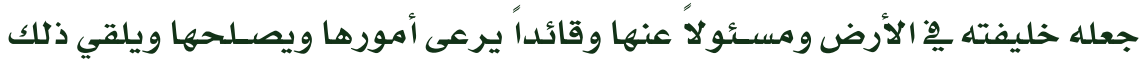

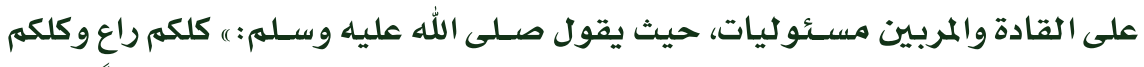
مسئول عن رعيته (.) 
فالقيـادة ظاهـرة اجتماعيـة توجـــ فِ كل موقف إجتماعي وتؤثر بِ نشـاط الجماعـة التي تسـى لتحقيـق أهداف معينـة والوجود الجماعي يفرض وجود من ينظم العلاققات بين أعضاء الجماعة، والقيادة ليست مكانه أو مركز بقدر ما هي إلا

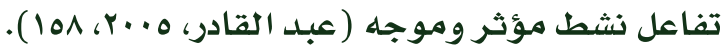

فيمثل مـجـال القيـادة والسـلوك القيـادي أحسـ أهم المجــالات التـي تناولها العديــد مـن الباحثين يِ العلوم الاجتماعية والنفسـية والتربويسة والإدارية ؛ وعليه

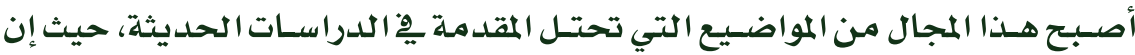
هذا الموضوع أبعاداً وجوانب إنسانية متعددة. إن ما توصـل إليه العلهم مِّ مجال القيادة والسـلوك القيادي ليمثل نتاج عمل له تاريخ طويل من البحث والتجربة والتطبيق، فقد انطلق الباحثون يِّ هذا المجال

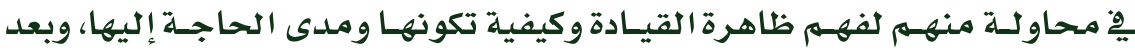
ذلك بدأت الجهود تنصسب حول وضـع إطار محدد لمفهوم القيادة والقائد، وذلك من

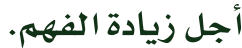

وهـع تصـاعد حلدة التغيرات التي تعيشـها المنظمات حالياً أصسبح لزاماً عليها أن تواجه التحديات التي تفرضـها الظروف البيئية بشـكل علهي منظم، حتى أصبح

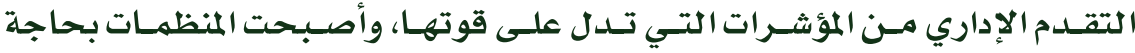

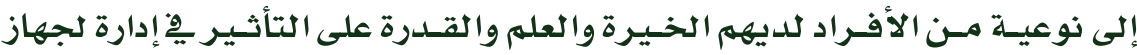
الاداري، فهي تحتاج كما يقول أوردي تيد (O Tead) إلى أن تُقاد أكثر مـن إن تُدار يِ

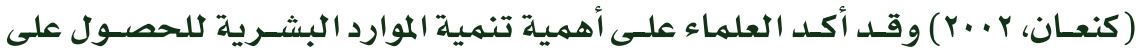

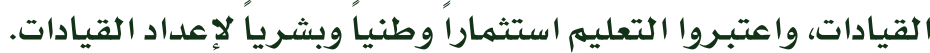

مفموم القيادة :

يُعـرف (2000) , أن القـادة هـــم أفـراد يؤثرون على \&anet \& Kronborg ألى أفكار عدد كبير من الأفراد ومشـاعرهم وسـلوكهم، والكثير من التربويين يؤمنون بأن المهارات المطلوبة يِّ القادة البارزين يهكن أن تعلم وتدرب بأسلوب مدروس. وذكـر (2003) أن القـــرة علـى إنجــاز عمـل مـع الآخريـن ومـن Stuart,

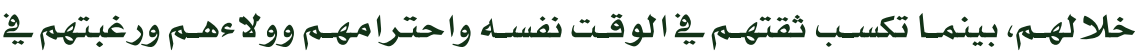
التعاون هي القيادة. 


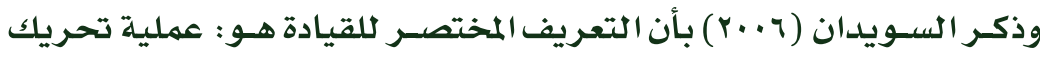
الناس نحو الهدف، ولهذا لا بد أن تكون للقائد صفات مهيزة تؤهله ذيكون على رأس الجماعة، والسراج المنير لمسيرتها حتى تصل إلى الهدف المنشود.

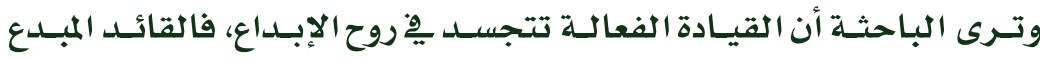
يستخدم المرونة والتفكير التكيفي لينتج استجابات مثمرة للبئيته.

\section{أممية القيادة :}

تمتلـئ حياتنـا اليومية ِِ عالمنا اليوم بالمواقف التي تـبـرز دور القيادة، الأمـر الذي يدعو إلى الاهتمام بالقيادة للأسباب التالية:

إن نجاح أو فشل أيـة جماعة أو مؤسسة إنها يعتمد إلى حلد بعيد على خصائص

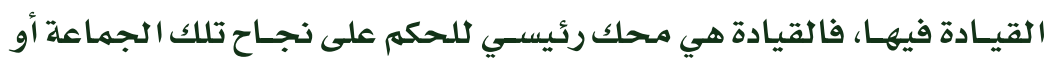

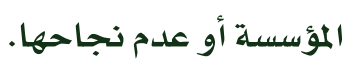

إن القادة ينهضون بدور فاعل فِ تحديد قدرة الأغلبية على الفعل ويفجرون

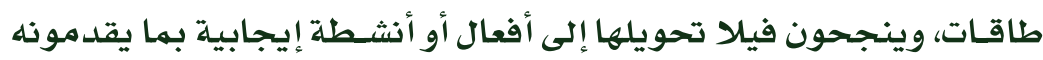
من أفكار إبداعية خلاقة تستهدف التحون التجديلد. تزايد الحاجة ِِ كل المجتمعات، إلى القادة القادرين على التتظيم والتطوير،

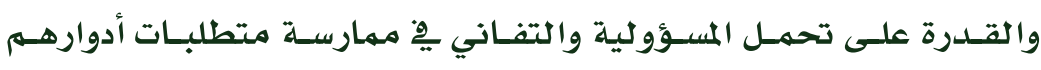
القيادية.

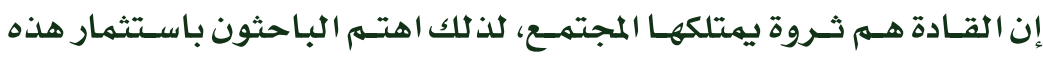
الثروة، ودراسة جميع المؤثرات التي تحافظ عليها (الطويل ...... ).

فالسلوك القيادي ووجود القائد الجيد على رأس عمله أمر يْ غاية الأهمية،

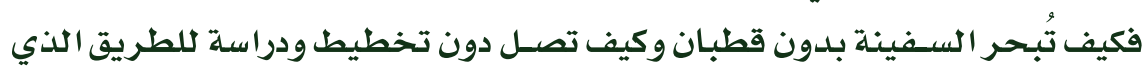

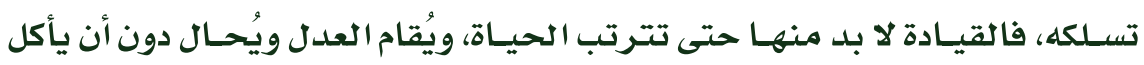

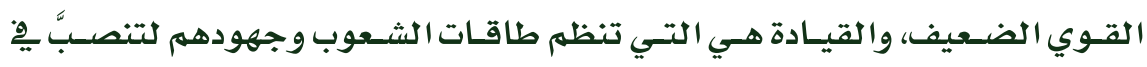

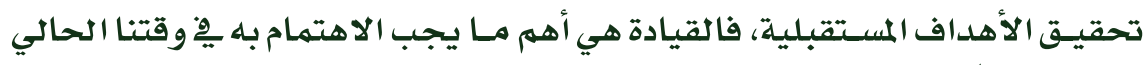

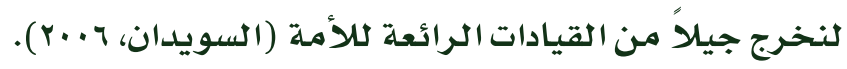


وفيما يلي التعريفات الإجرائية لمهارات القيادة الأربعة التي تم اختيارها من

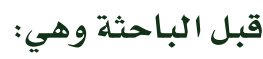

The skill of the decision - مهارة اتخـاذ القـرار وحسل المشـكلات

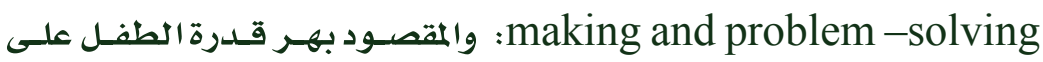

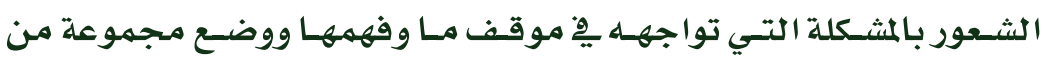

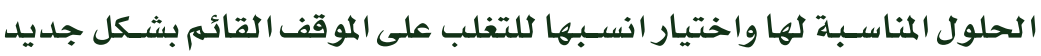

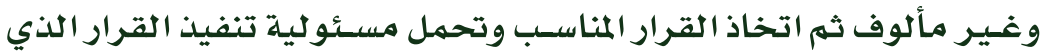
توصل إليه.

مهارة التواصل مـع الأقران Skill to communicate with peers: هي إنه

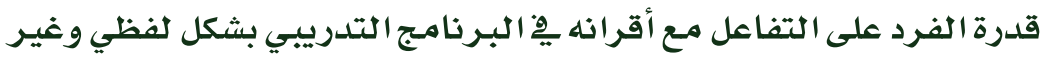

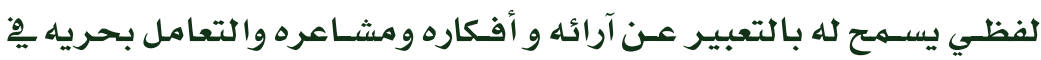

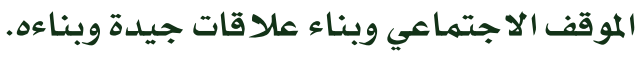

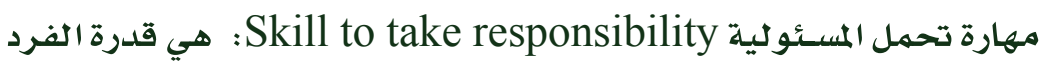

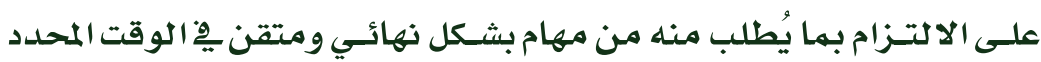
كله وتحمل نتائج تصرفاته و أفعاله.

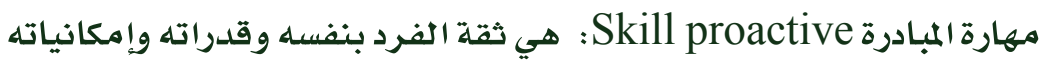

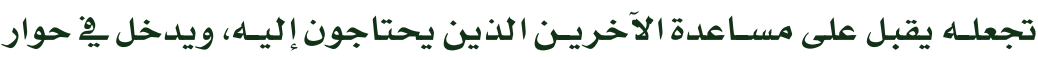

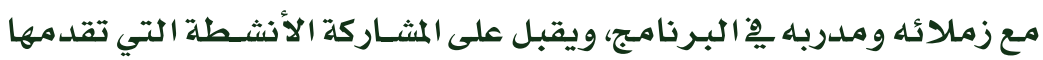
الباحثة (المدربة) مسبقا قبل الآخرين ودون أن يطلب ولب ذلك.

فروض البحث:

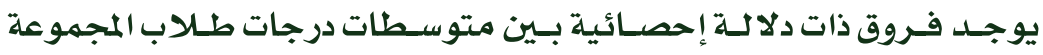

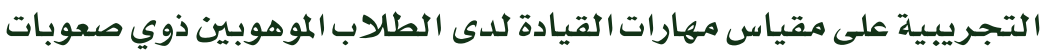
التعلم قبل وبعد البرنامج لصالح التطبيق البعدي.

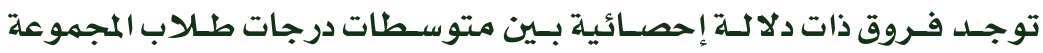

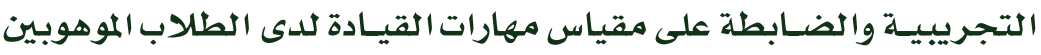

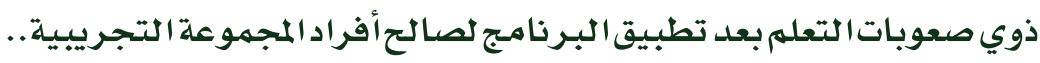


لا يحقق اسـتخدام برنامج قبعات التفكير السـت أثراً كبيراً ِِِ تنمية مهارات السـلوك القيـادي لدى طلاب وطالبـات المرحلة الثانويلة مـن الموهوبين ذوي

$$
\text { صعوبات التعلهم. }
$$

$$
\text { إجر ابوات البحثث: }
$$

عقـــت الباحثـة مقابـلات مـع بعض من الآبـاء والأمههات والمعلمـين وبـخاصـة

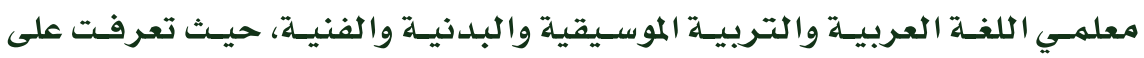

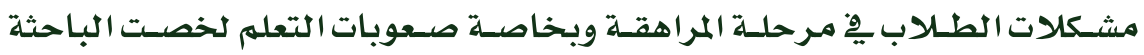
أهم تلك المشـكلات والسـلوكيات السلبية التي يعانيها الموهوبون ذوو صعوبات التعلم والتـي تمحسورت حول المثـكلات الناجمـة عـن التنشـئهة الاجتمـاعيـة الخاطئة مثل :

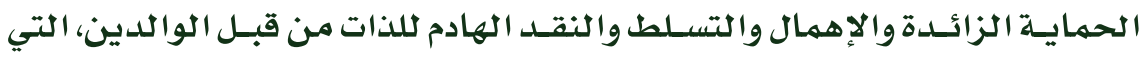
تؤثر بلدورها يِّ تدني احترامهم لذواتهم، فينتج الشعور بالإحباط وانخفاض الثقة وعدم قدرتهم على حل المشـكلات خصوصـا عند تكليفهم بهمهام صسعبة فسيشـعرون دوما بالعجز وتقل دافعيتهم وتقديرهم لذواتهم.

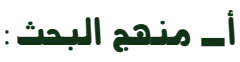
منمي البحث :

اسـتخدم البـحـث الحالي المنهج (شـبـه التجريبـي) ليلائمر متغيـرات الدراســة

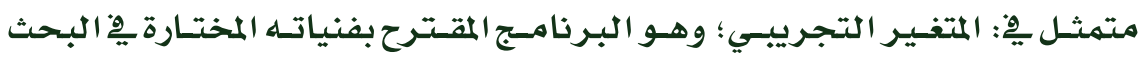
الحالي وهي (القبعات الست) يخ التفكير، والمتفير التابع ؛ وهو المهارات القيادية لدى ولى

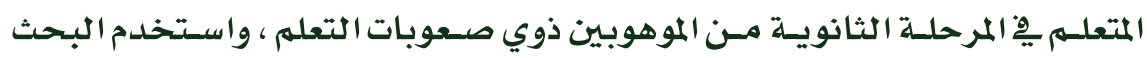
الحالي التصسميهم شبـه التجريبي ذي المجموعتين حيث يتم القياس القبلي والبعدي

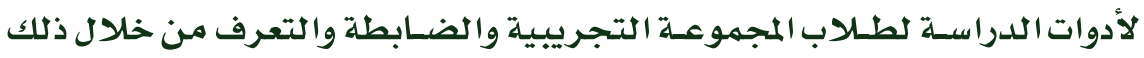
على أثـر المتغـير التجريبـي (البـرنامـج المقترح) على المتفيـر التابع (بعض المهارات القيادية لدى طلاب المرحلة الثانوية من الموهوبين ذوي صعوبات التعله).

\section{شروط اختيار العينة مي : (1)} عمر الطالب أو /الطالبة بين 10 -17 سـنـة بهتوسـك 0,010 وانحراف معياري ج7, •، راعت الباحثة فاصلا زمنيا' لتحديد العينة (ترم دراسي كامل). أنهم جميعا لا يعانين من أية إعاقات أخرى وفقاً لتقارير المعلمين. 


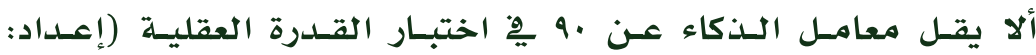

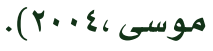

الحصول على درجة مرتفعة يِّ مقياس الخصائص السلوكية لذوي صعوبات

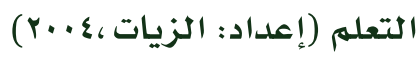

الحصـول على درجـة عاليـة ِِّ مقياسـ الأنشــة الابتكاريسة Torrance

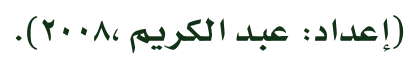

حصـولهم على درجة مرتفعة يِّ مقياس خصـائص الموهوبين ذوي صـعوبات

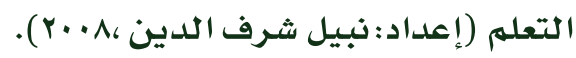

بـ الأدوات المستخدمة:

أدوات ضبط العينة :

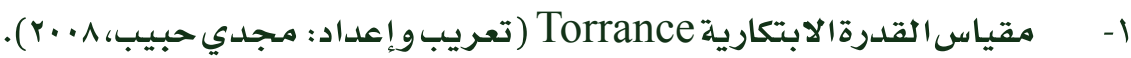

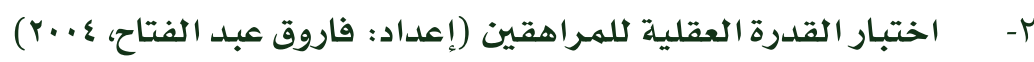

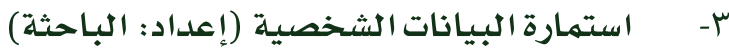

Q $\quad$ أدوات قياس وتشفيص العينة

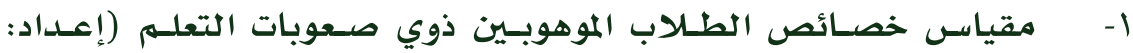

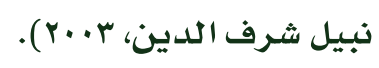

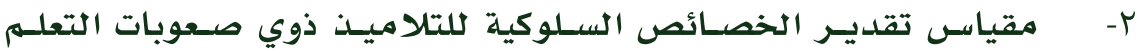

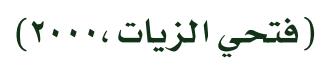

ب- مقياس مهارات السلوك القيادي (إعداد: الباحثة)

أولاً : مقياس السلوك القيادي : أست

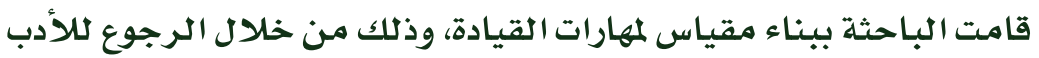

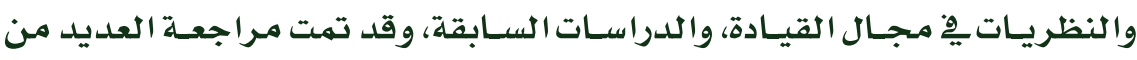

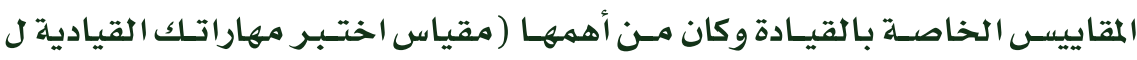

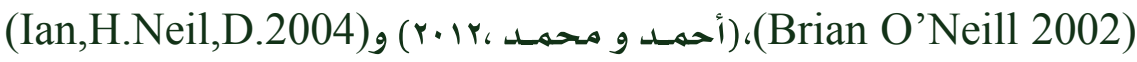
مقياس المهارات القيادية ل) (Karnes \& Chauvin 2005 ومن ذلك قامت الباحثة

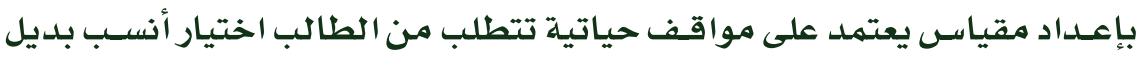

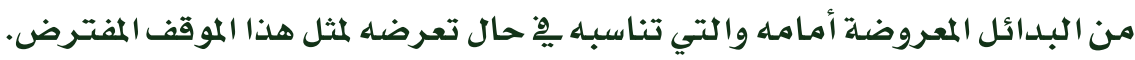


ويشـمل مقياس السـلوك القيادي يِّا لبحث الحالي على ( •ع ) موقفا، يصف

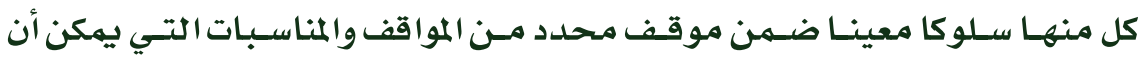

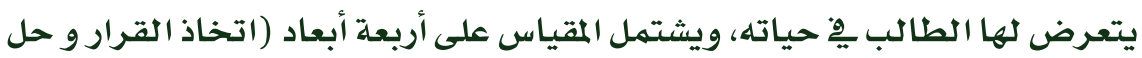
المشـكلات / تحمل المسـؤولية / التواصـل / المبادرة) ولكل بعد ( •(1)عبارات، وتصـاغ ثلاث استـابات لكل موقف يوضـح السلوك القيادي احدى هذه الاستجابات توضـح السـلوك القيـادي إما (المرتفع / المتوســ / المنخفض) وقد رتبـت الباحثة الفقرات عشـوائياً لكل كوقف من مواقف السـلوك القيادي.وتم عرض المقياس على مجموعة من الأسـاتذة المختصسين يِّ كل من علم النفس، وعلوم التربية، من أجل إبـاء رأيهم

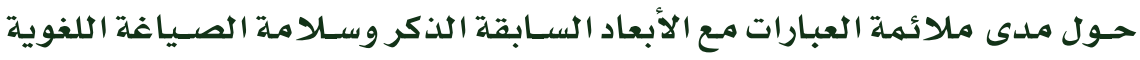

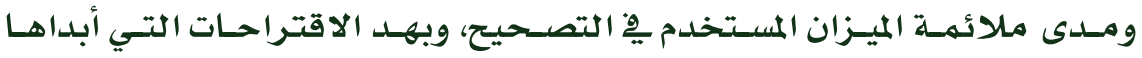

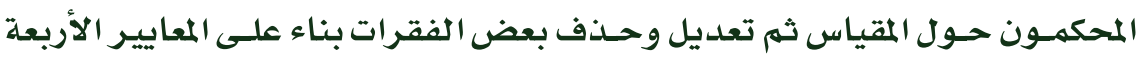

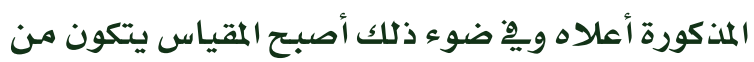

صدق المقيساس : تم التحقق من صدق المقياس بطرقتين: أولا : صدق المدتوى

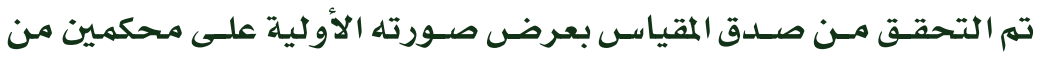

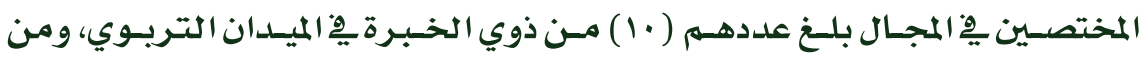
الأسـاتذة يِّ جامعات (المنصـورة ،طنطا ،بنها) ) بهدف الحكم على سـلامهة العبارات و مناسبـة العبارات لكل بعد، وعلى ضوء مالاحظاتهم وآرائهم تم تعديل أسئلة المقياس حيـث تم تعلديـل صـياغة بعض العبارات لتتلاءم مـع مسـتوى الطلاب واسـتنادا إلى ملاحظات المحكمين اللغوية أعيدت صياغة بعض العبارات لغويا. ثانيا : الصدق التلازمي

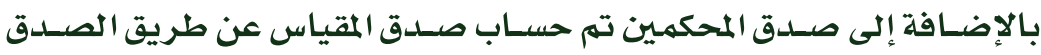
التلازمسي هـع مقياس آخر يقيس السلوك القيادي، وهو من إعداد (الرفاعي 1911)

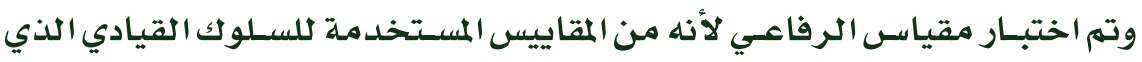

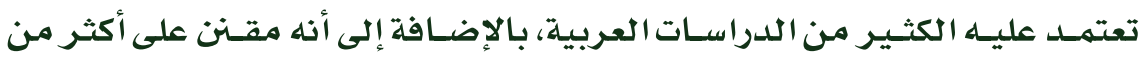
دولة عربية (الأردن، فلسطين). 
طبقــت الباحثـة مقياسـ الرفاعي على عينة اســطلا عية والذين هم ضـمن

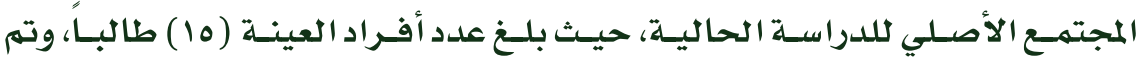
تطبيق مقياس السـلولك القيادي من إعداد الباحثة على العينـة نفسـها، وباسـتخدام معامل ارتباط (بيرسون) لحساب معامل الارتباط بين أفراد العينة على المقياسين،

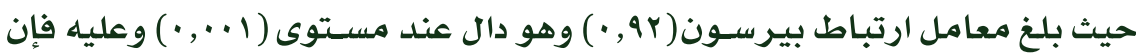
هذه النتيجة تشير إلى صدق المقياس.

ثبات المقياس : (x)

قامست الباحثـة بتطبيق المقياس على عينة اسـتطلاعية من المرحلة العمـرية نفسـها، واشـتملت العينـة على (10) طالبا' مـن طلبـة المرحلة الثانوية الصـف الأول الثانوي ،ويهدف الباحث من وراء تطبيقه على العينـة الاستطلاعية إلى بيان وضوح تعليمات المقياس والزمن المسـتغرق والصسعوبات المحتملة يِّا البنود، وهل هي واضحة

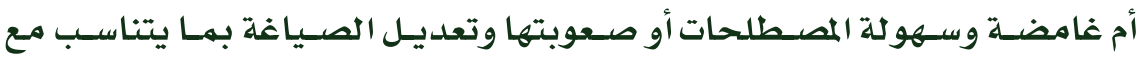
مستوى الطلبـة.

كذنك كان الهدف من تطبيق المقياس على عينة استطلاعية هو التحقق من ثبات المقياس وبعد

الانتهاء من التجربة الاستطلاعية، تبين ملاءهمة المقياس للمرحلة العمـرية، وأن المدة الزمنية للإجابة على جميع بنود المقياس من ( r. ) إلى (Yo ) دقيقة، وقد تم حساب ثبات مقياس السلولك القيادي بعد تطبيقه بطريقتين:

أولا : طريقة الاتساق الداخلي تم حساب الثبات بطريقة الاتساق الداخلي (ألفا كرونباخ) جيث بلغ (^^, •)، كما حسب الثبات بطريقة الاتساق الداخلي كلأبعاد المكونة للمقياس، والجدول (r) يوضـح نتائج معامـلات الاتسـاق الداخلي لأبعاد الرئيسـية للمقياس والمجموع الكلي للسرجات. 


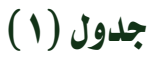

معاملات الاتساق الداخلي لمقياس السلوك القيادي وأبعاد المقياس

\begin{tabular}{|c|c|c|}
\hline معامل ألفـا & عدد الفقرات & الأبعاد الرئيسـية \\
\hline$\cdot, \mathrm{\vee} \wedge$ & 1. & البعـد الأول (مهـارة اتخـاذ القرار وحـل المشـكلات) \\
\hline$\cdot, \mathrm{V} \varepsilon$ & 1. & البعد الثاني (مهارة التواصل مع الأقران) \\
\hline$\cdot, \mathrm{VV}$ & 1. & البعـد الثالث (مهـارة خحمـل المسـئولية) \\
\hline$\cdot, \wedge$. & 1. & البعـد الرابع (مهارة المبادرة) \\
\hline זג, & $\varepsilon$. & الجُموع الكلي للمقياس \\
\hline
\end{tabular}

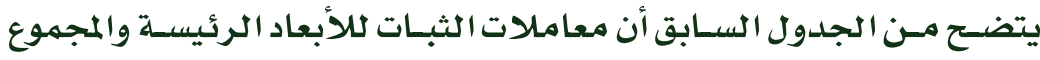

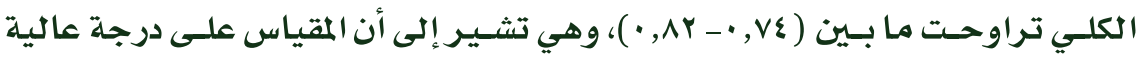
من الثبات.

\section{ثانيا : إعادة التطبيق}

تم اسـتخدام أسـلوب إعـادة التطبيـق (Test-Retest) بعـــ أسـبوعين مـن التطبيق الأول على العينـة الاستطلا عية، ويوضـح الجدول (r) معاملات الارتبـاط لمقياس السلوك القيادي يِ إعادة التطبيق.

\section{جل جلدول (r)}

معاملات الارتباط لمقياس السلوك القيادي والأبعاد في إعادة التطبيق

\begin{tabular}{|c|c|}
\hline 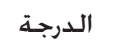 & مقياس السـلوك القيادي \\
\hline$* * \cdot, \Sigma \wedge \varepsilon$ & البعـد الأول (مهـارة اتخـاذ القرار وحـل المشـكلات) \\
\hline$* * \cdot, 1 \wedge \vee$ & البعد الثاني (مهارة التواصل مع الأقران) \\
\hline 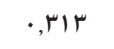 & البعـد الثالث (مهارة خحمـل المسـئولية) \\
\hline$\cdot, r \mathrm{VI}$ & البعد الرابع (مهارة المبادرة) \\
\hline$* *, q \mu \varepsilon$ & الجُمـوع الكلي للمقياس \\
\hline
\end{tabular}

وجميع أبعاد المقياس دالة مها يعطي مؤشراً على أن المقياس على درجة عالية من الثبات. 


\section{تصحيـ مقياس السلوك القيادي:}

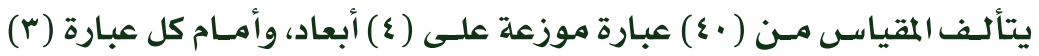

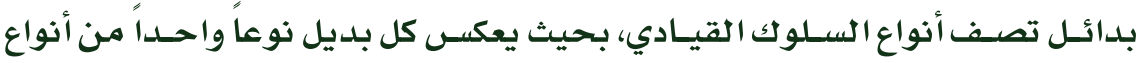

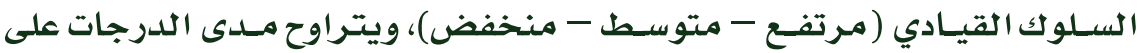

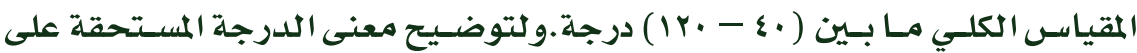

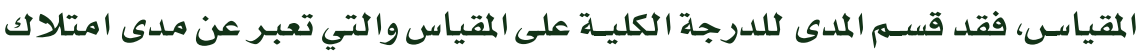

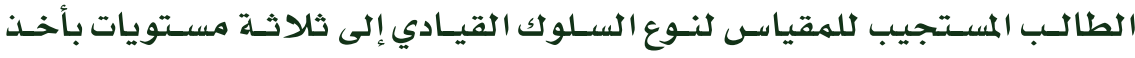

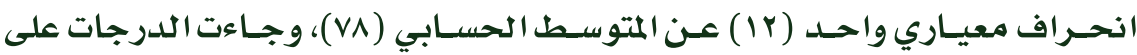

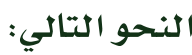

$$
\begin{aligned}
& \text { الدرجة التي تمثل السلوك القيادي المنخفض من ( ع ؛) إلى (10) درجة. }
\end{aligned}
$$

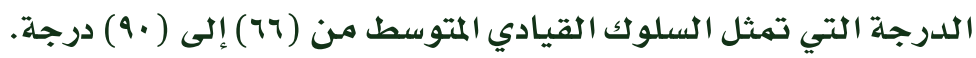

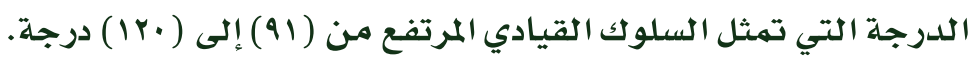

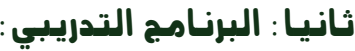

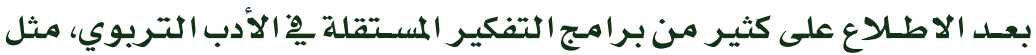

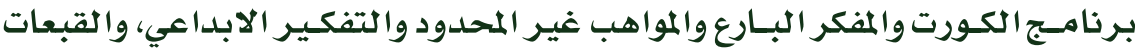

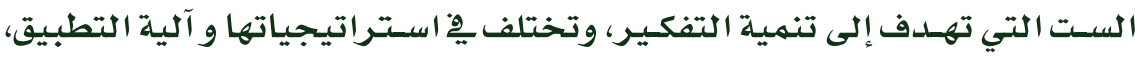

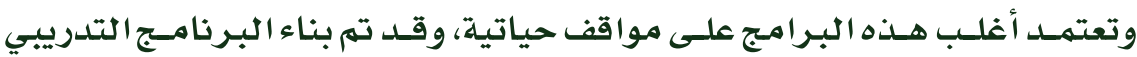

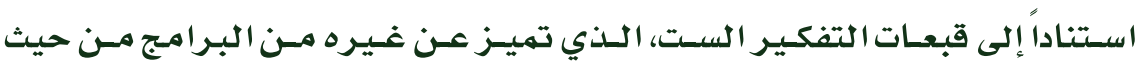

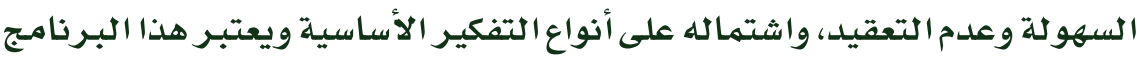

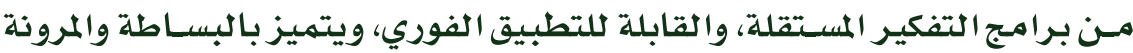
وسهولة التنفيذ، ويمكن تطبيقه على كافة المراحل العمرية.

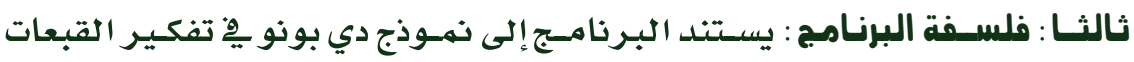

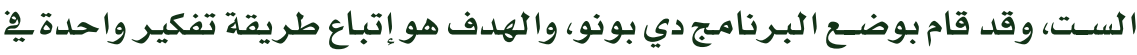

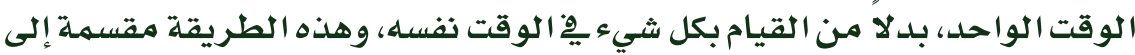

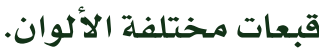


القبعـة الحمــراء: وتعنـي أن التفكير يعتمد على اسـتخدام الحدس، ويتأثر

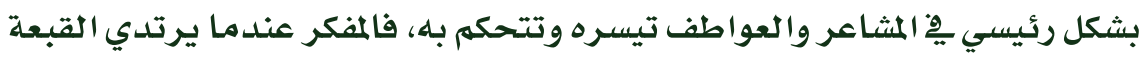
الحمراء فهو يستبعد المنطق والمبررات.

رابعا : افتراضـات البرنـامي : يسـتند البـرنامـج على نظرية دي بونو للقبعات السـت، مفهـ التـي يعرض مؤلف النظرية مفهوما بسـيطا يتيح الفرصسة للمفكـر أن يقوم بعمل واحد يِّالوقت الواحد، وبهذا يفهل بين العاطفة والمنطق، وبين الإبداع والمعلومات

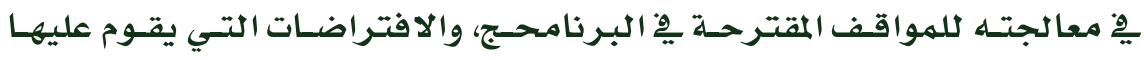

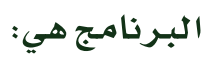

$$
\text { لعب الأدوار من خهلا التبر التدريب عليه وتتهيته. }
$$

استخدام جميع أنواع التفكير ِِّف مشكلة تعليمية أو موقفية.

مـدف البرنـامــ العام: هـــف البـرنامـج العام هو تبسـيط التفكير والسـهـاح للهفكر

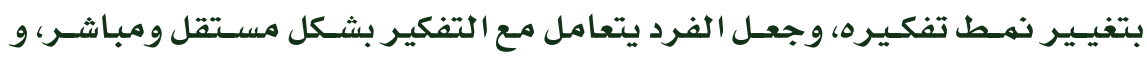

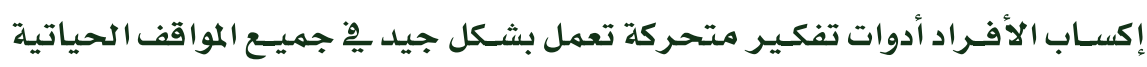
المختلفة، ويهدف البـرنامـج بشكل خاص يخ هذه الدراسـة إلى ما يلي: تنمية السلوك القيادي لدى الموهوبين ذوي صعوبات التعلم. مـدة تطبيـق البرنـاميم: قامست الباحثة بتطبيـق البـرنامج خلال الفصـل الأول من

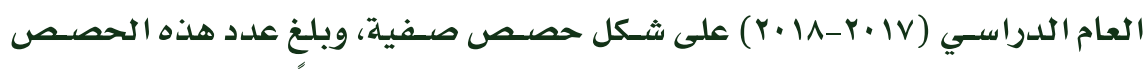
(rr) حصة مدة كل حصدة (0ع) دقيقة، موزعة على (1N) درساً

المحاور الرئيسة للبرنـامي : يقوم البـرنامج على ثلاثة محاور رئيسة: المحور النظري: ويتمثل يِ تقديم المعلومات عن التفكير والقبعات الست. المحور العملي: ويتمثل يِ التدريب على كيفية استخدام استراتيجيات قبعات التفكير الست. المحـور القياسـي: ويتمثـل فِ قياس السـلوك القيادي من خـلال الاختبـارات

$$
\text { القبلية والبعدية }
$$




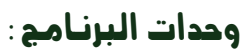

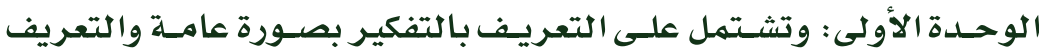

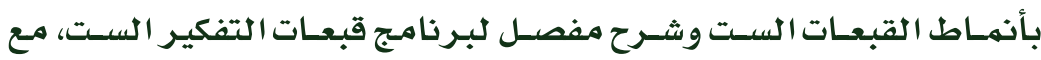

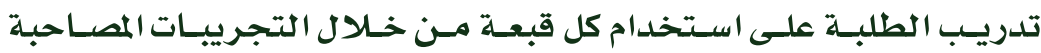

$$
\text { للوحدة الأولى. تلى الطلي. }
$$

الوحسـة الثانيـة : وتتركز حول التـريب على القبعات السـت بشـكل منفصـل

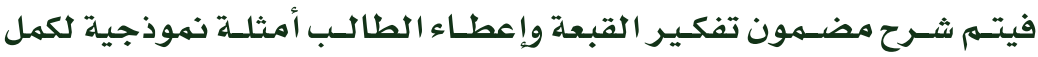
قبعة على بعض التماتلاين وأوراق العمل المصاحبة للوحدة الثاندانية.

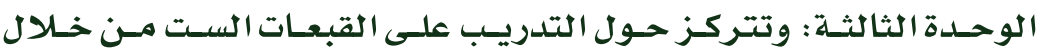

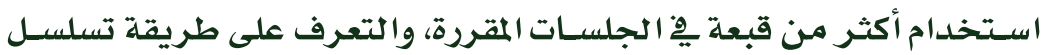

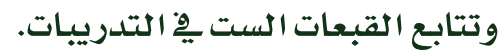
الأدوات والوسائل المستفدمة في البرنـامي :

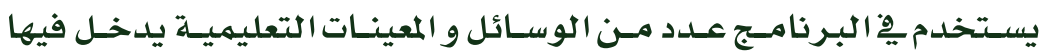

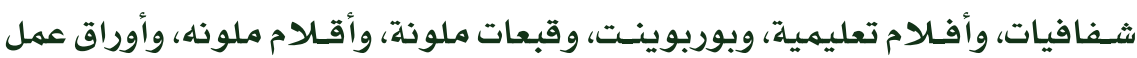

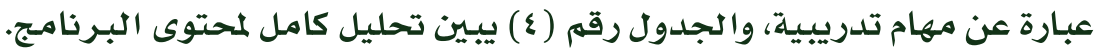




\section{جدول (r)}

توزيع وحدات وجلسـات البـرنامـج

\begin{tabular}{|c|c|c|c|}
\hline عدد الجـلسـات & عنوان الدرس & 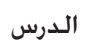 & وحـدات البرنامه \\
\hline 1 & لقاء تعريفي & 1 & \multirow{5}{*}{ الوحدة الأولى } \\
\hline 1 & مقدمة عن التفكير & r & \\
\hline r & مدخل إلى القبعـات السـت & $r$ & \\
\hline 1 & مباديء الابداع فيلم & $\varepsilon$ & \\
\hline r & التمييز بين القبعات الســت & $\Delta$ & \\
\hline r & القبعة البيضاء & 1 & \multirow{4}{*}{ الوحدة الثانية } \\
\hline r & القبعة الحمبراء & $v$ & \\
\hline r & القبعة الصفراء & $\wedge$ & \\
\hline r & القبعة السـوداء & 9 & \\
\hline r & القبعة الخضـراء & 1. & \\
\hline r & القبعـة الزرقاء & 11 & \\
\hline r & حياة حشـرة فيله & 15 & \\
\hline r & التمييز بين القبعـات السـت & 14 & \\
\hline r & اســخــام تتابعي للقبعـات الســت & $1 \varepsilon$ & \\
\hline r & القبـعـة البيضـاء والحـوارء والرزقاء & 10 & \\
\hline$r$ & الخضضراء والصفـراء والســوداء & 11 & \\
\hline r & تطبيقـات شـاملة للقبعات السـت & IV & \\
\hline r & التمييز بين القبعـات السـت & 11 & \\
\hline
\end{tabular}

وقـد أجـري التحليـل باسـتخدام(T-test) لفحص الفروق بــين المجموعتين

$$
\text { (التجريبية، الضابطة). }
$$

ويظهـر الجـدول (0) أن الفـروق بـين المجموعـة التجريبية والضـابطة غير

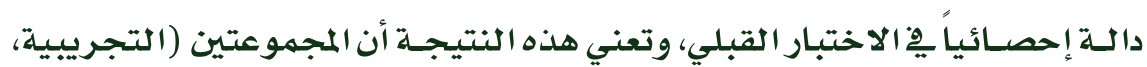

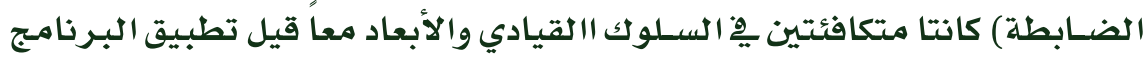
،وهذا ما تشير إليه قيم متوسطات المجموعتين (التجريبية، الضابطة). 


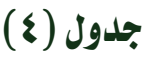

المتوسطات والانحر افات المعيارية لدرجات الطلبة على السلوك القيادي

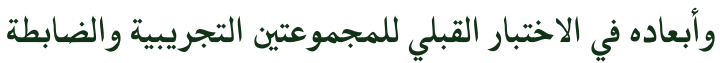

\begin{tabular}{|c|c|c|c|c|c|c|}
\hline \multirow{2}{*}{ مســـوى الدلالة } & \multirow{2}{*}{ قيمـة ت } & \multicolumn{2}{|c|}{ التجـريبية } & \multicolumn{2}{|c|}{ الضابطة } & \multirow{2}{*}{ المتغيرات } \\
\hline & & انـحــراف & متوسـط & انـحـراف & متوسـط & \\
\hline$\cdot, \wedge V \Psi$ & $\cdot, 17$. & $r, 9 r$ & $r \cdot, \cdot \Delta$ & $\Gamma, 1 \varepsilon$. & 19,90 & 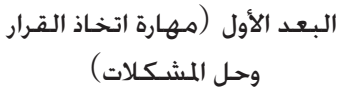 \\
\hline$\cdot, \wedge\lceil\wedge$ & $\cdot, \Gamma \wedge$ & $\Gamma, \sum V$ & $1 \wedge, \Sigma \Gamma \Delta$ & $\Gamma, 1 \varepsilon$. & $1 \wedge, \Delta \Delta$ & البعـد الثاني (مهارة التواصل \\
\hline$\cdot, \mathrm{Vq}$. & •, ז TV & $r, 1$. & $I \wedge, \wedge \vee$ & $\mathrm{r}, \mathrm{V} r$ & $19, \cdot 0$ & البـعـد الثالث (مهارة خـمـل \\
\hline$\cdot, 9\lceil\wedge$ & $\cdot, r \wedge \wedge$ & $\Gamma, \Delta \Lambda$ & $r \cdot, \mathrm{VV}$ & س r, & $\Gamma \cdot, \wedge \Gamma$ & البعـد الرابع (مهارة المبادرة) \\
\hline$\cdot, \wedge \leq 9$ & $\cdot, 195$ & $1, \Gamma \wedge$ & $V \wedge, I \Gamma \Delta$ & $\Delta, r \varepsilon$ & $V \wedge, r v$ & الجمـمـوع الكـلي للمقيـاس \\
\hline
\end{tabular}

نتائج البحث وتفنسير ها

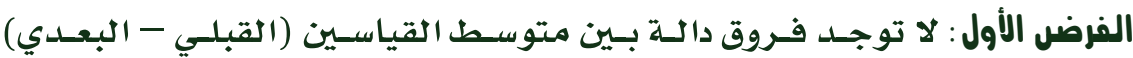

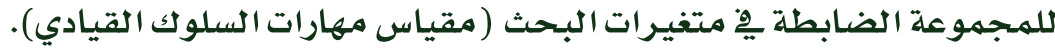

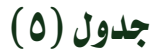

دلالة الفروق بين متوسط القياسين (القبلي - البعدي) للمجموعة الضابطة في متغيرات البحث

\begin{tabular}{|c|c|c|c|c|c|c|}
\hline \multirow{2}{*}{ 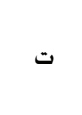 } & \multicolumn{2}{|c|}{ القياس البعدى } & \multicolumn{2}{|c|}{ القياس القبلى } & \multirow{2}{*}{\multicolumn{2}{|c|}{ متوسط }} \\
\hline & & انحراف & متوسط & انحراف & & \\
\hline$\cdot$ - ¿A1 & $17, r v a$ & $\vee \wedge, \wedge \Delta$ & IV, II & $v q, 0 .$. & $1 \mu=0$ & الضابطة \\
\hline
\end{tabular}

$$
\text { قيمة ت الجدولية عند مستوى الدلالة ه., • = } 07 \text {. }
$$

يتضـح من جدول ( آ أن الفروق بين القياسـين (القبلي- البعدي) غير دالة وذلك لأن قيمة ت المحسوبة أقل من قيمة الجدول اندانية. 


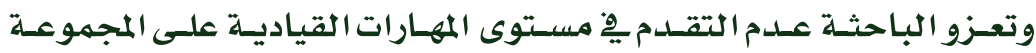

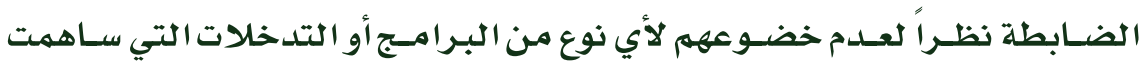

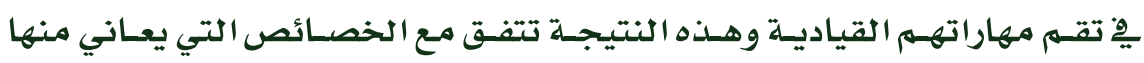

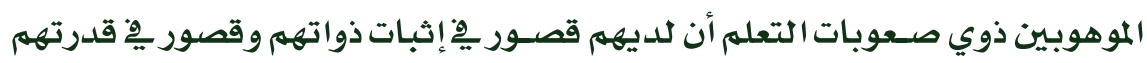
على ( حل المشـكلات واتخاذ القرار، المبادرة، تحمل المسـؤولية، التواصـل مـع الأقران) نظـراً للصعوبـة المقنعـة التي يواجهونهـا، فلا يـزال الموهوبون ذوو صـعوبات التعلم

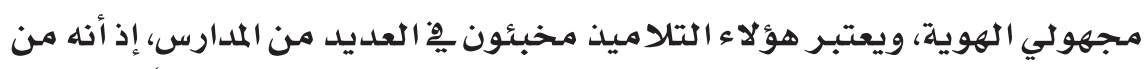

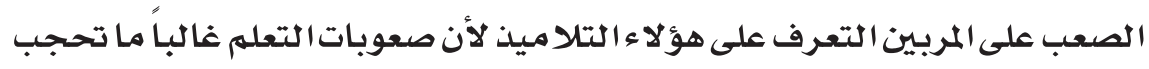

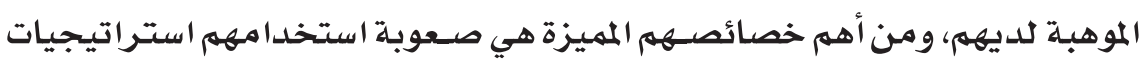
منظمة لحل المثكلات، فلا يهتلكون القدرة على تعميه طريقة حل المشكلة ذاتها عند اختلاف المواقف وتشـابه الظروف، كما أن لديهم صسعوبة يِ التواصـل مـع الآخرين (لفظي - مكتوب) فيعاني الطالب الموهوب ذوي الصعوبات التعليمية من مشاكل يخ

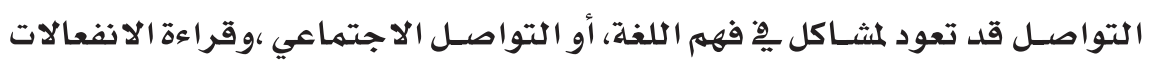
العامـة (متولي، والقحطاني، 10 •r، 190).

\section{ثانيا : عرض نتائي الفرض الثانى ومنـاقشتما :}

توجـــ فـروق دالة بـين متوسـط القياسـين (القبلـي - البعـدي) للمجموعة

$$
\text { التجريبية يِّ متغيرات البحث (مقياس مهارات السلوك القيادي). }
$$

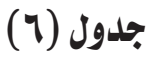

دلالة الفروق بين متوسط القياسين (القبلي - البعدي) للمجموعة التجريبية في متغيرات البحث

\begin{tabular}{|c|c|c|c|c|c|c|}
\hline \multirow{3}{*}{$\begin{array}{c}ت \\
\Gamma, r \leq 1\end{array}$} & \multicolumn{2}{|c|}{ القياس البعدى } & \multicolumn{2}{|c|}{ القياس القبلى } & \multirow{2}{*}{\multicolumn{2}{|c|}{ المتغيرات }} \\
\hline & & انحـراف & متوسط & انحـراف & & \\
\hline & IE, IV. & 94,195 & $1,1 \wedge \wedge$ & $q \cdot, \wedge \sum 1$ & ن & التجريبية \\
\hline
\end{tabular}

$$
\text { قيمة ت الجدولية عند مستوى الدلالة هـ }
$$

يتضح من جدول (V) أن الفروق بين القياسين (القبلي- البعدي) للهجموعة التجريبية (الخاضعة للبرنامـج القائم على استراتيجية قبعات التفكير الست) دانة

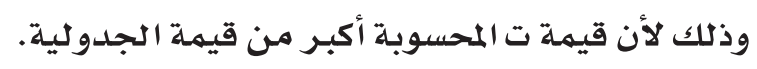


تعـزو البـاحثة إلى وجود فروق دالة بـين القياس القبلي والبعدي للمجمبوعة

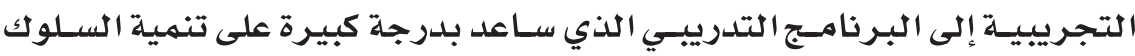

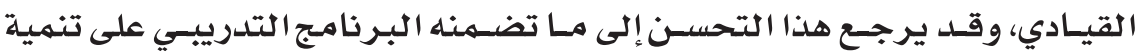

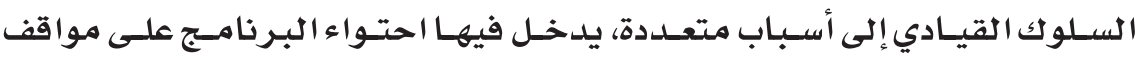
و مشـكلات واقعيـة يتعرض لها الطالب يِ حياتـه اليومية وتثيـر اهتمامهـ، وكذلك تتطلسب منـه اتخاذ موقف معين أو تحمل مسـؤولية أو المبـادرة، وكذلك يهكن القول

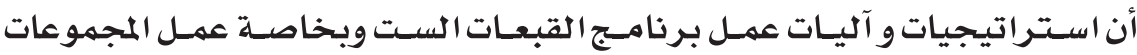
وتوزيـع الأدوار واسـتخدام القبـــة الزرقاء سـاعد بطريقة غيـر مباشــرة على تنهية (اتخاذ القرار ، تحمل المسـئولية، المبادرة، تواصـل الأقران)، فالعمل داخل المجموعة والتحدث باسم المجموعة والمنافسة بين المجموعات و عمليات التفكير بيين المجموعات سـاعد ذلك فِ تتميلة السـلوك القيادي لدى الطلبـة. وتتفق هذه النتيجة مـع دراسـة

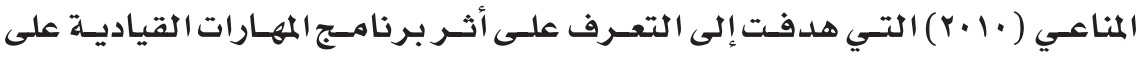

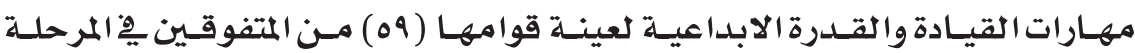
الثانويـة وتوصـلت إلى وجـود فـروق ايجابية يِ القـدرة الابــا عية بــين المجموعتين الضابطة والتجريبية لصالح التجريبية.

ثالثا: عرض نتائم الفرض الثالث ومنـاقشتما وتفسيرها توجـــ فـروق دالـة بـين متوسـطي القياسـين (القبلـي - البعـدى) بـين المجموعتين (الضابطة - التجريبية) يفّ مقياس مهارات السلوك القيادي

(V) جدول)

دلالة فرق الفروق بين متوسطي القياسين ( القبلي - البعدى)

بين المجموعتين ( الضابطة - التجريبية) في مقياس مهارات السلوك القيادي

\begin{tabular}{|c|c|c|c|}
\hline \multirow{2}{*}{ ت } & \multicolumn{2}{|c|}{ القياس البعـدي } & \multirow{2}{*}{ المتغيرات } \\
\hline & انحـراف & متوسط & \\
\hline \multirow[t]{2}{*}{$\varepsilon, \varepsilon \Delta T$} & $11, r \vee \wedge \wedge r$ & $\vee \wedge, \wedge \wedge \Sigma 1$ & الضـابطة \\
\hline & $I \Sigma, \mid V \cdot \Sigma 0$ & $9 \Lambda, 191 \pi$ & التجـريبية \\
\hline
\end{tabular}

قيمة (ت) الجدولية عند مستوى الدلالة ه., = 
يتضـح مـن جــدول (^) أن الفـروق بـين القيـاسـين (البعديـين) للمجموعـة

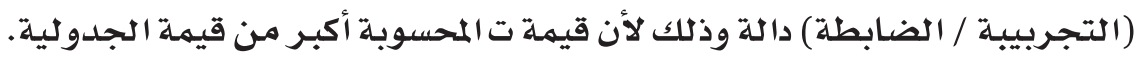

تعـزو البـاحثـة إلى وجـود فـروق دانـة بــين القياســين البعديـين للمجموعـة

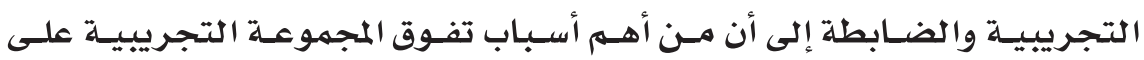

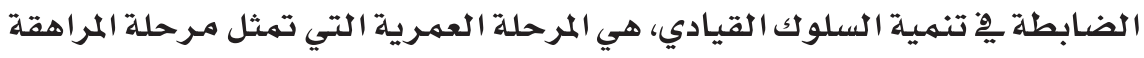

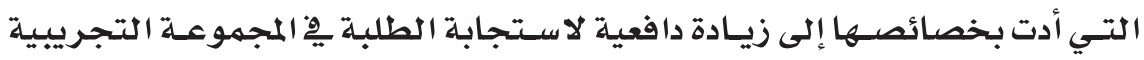

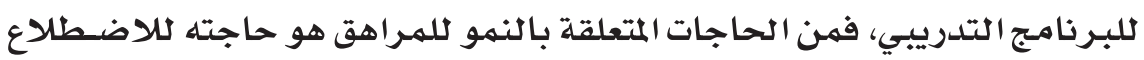

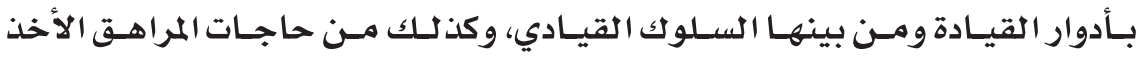
بزمام المبادرة يِّا التنظيمات الاجتماعية، وقد تشـبع هذه الحاجة الأنثـطة المختلفة

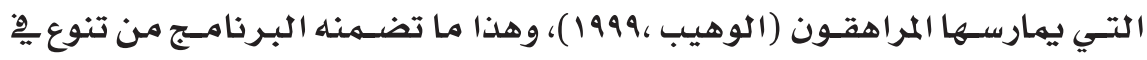
الأنثـطة، وتبـادل الأدوار كل ذلـك زاد من تفاعل الطلبـة والقيام بـأداء وكتابة أوراق

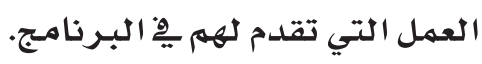

والنتيـجـة هذه تبـين فاعلية البـرنامـج التدريبي القائمر على قبعات التفكير

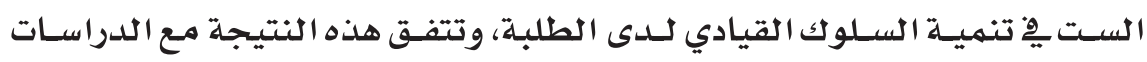

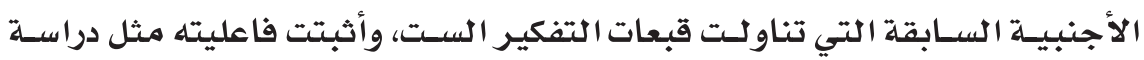

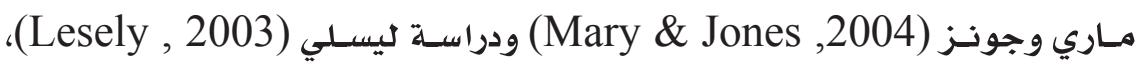
فقد أثبتت نتائج هذه الدراسـات فاعلية برنامـج قبعات التفكير السـت و أسفرت تلك وداتك

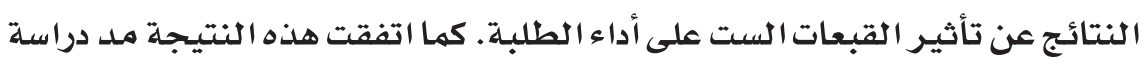

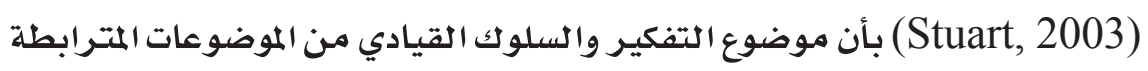

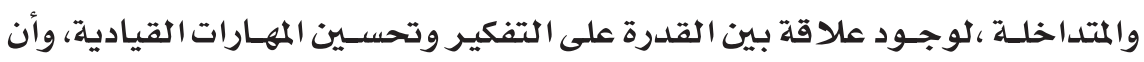

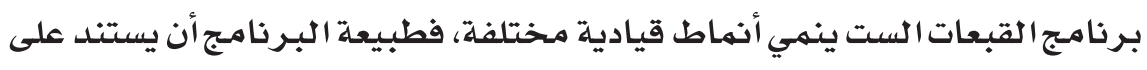
حـل المشـكلات والتفكير الإبلداعي والتفكير الناقد التي هي من سـمات وخصـائص

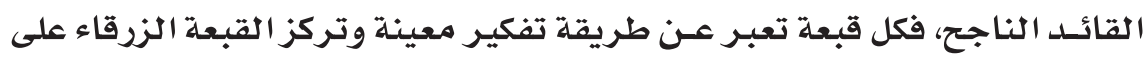
السلوك القيادي. 


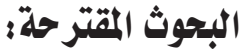

تم اقتراح عدة دراسات بالاستناد إلى نتائج البحث الحالي وهي:

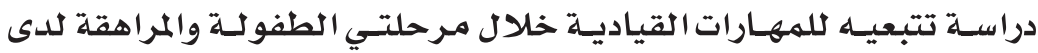

الموهوبين ذوي صعوبات التعله.

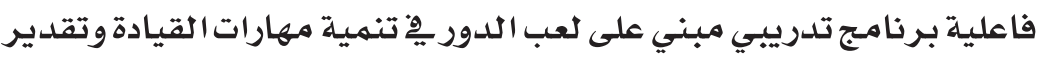

الذات لدى الموهوبين ذوي صعوبات التعله.

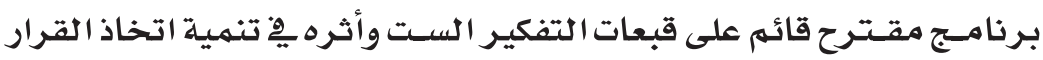

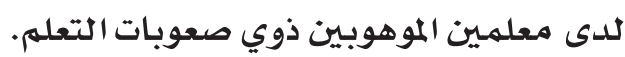

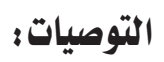

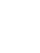

بناء على النتائج التي توصـلت إليها هذه الدراسـة، والتي أثبتت من خلا لها أهمية التفكير، تقترح الباحثة مجموعة من التوصيات هي:

ضرورة إدخال مادة مستقلة خاصة يِّ تعليم برامج التفكير المستقلة.

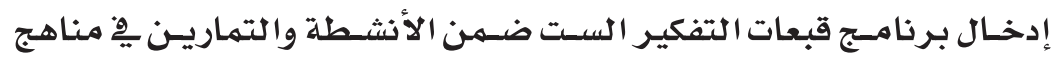

$$
\text { المواد الدراسية. }
$$

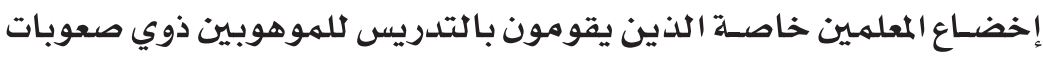

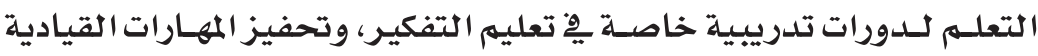

لديقهم وتنميتها.

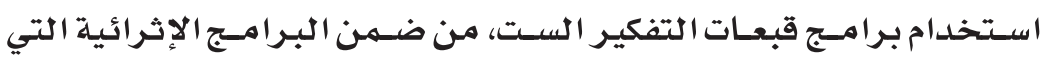

تقدمها الوزارة للطلبة الموهوبين.

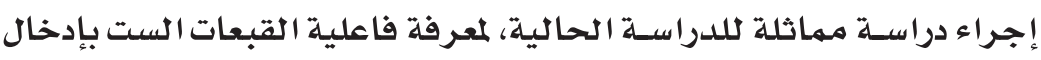

متغيرات أخرى كمتغير الجنس (ذكور، إناث) .

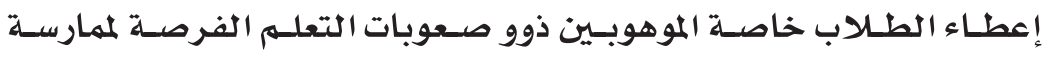

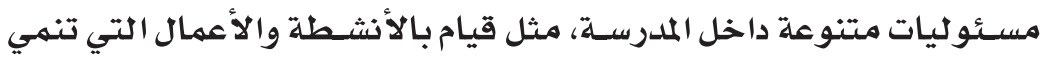

$$
\text { لديهم المسئولية وحب التعاون مـع الآخرين. }
$$

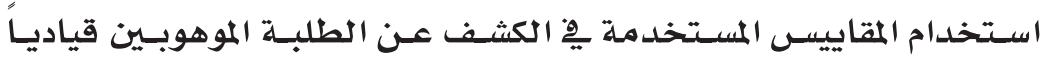

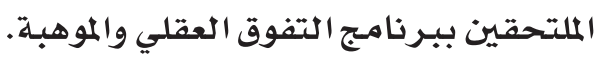

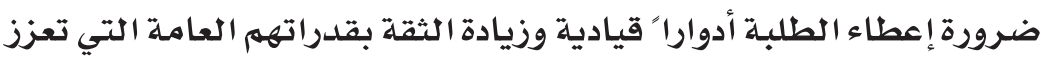

ثقتهم بأنفسهم 


\section{المراجع}

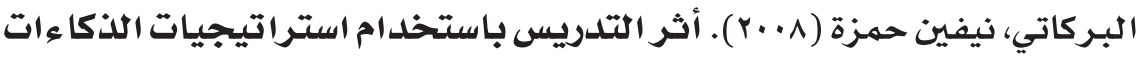

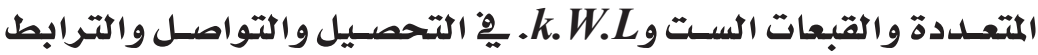

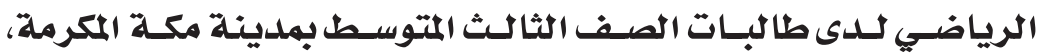
رسالة دكتوراه غير منشورة، جامعة أم القرى، كلية التربية.

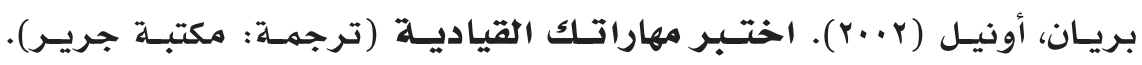

$$
\text { الرياض: مكتبة جرير. }
$$

جروان، فتحي (Y. . r). الإبداع. عمان: دار الفكر للطباعة والنشر والتوزيع. جروان، فتحي (Y.r. r). تعليم التفكير مفاهيم وتطبيقات. عمان: دار الفكر.

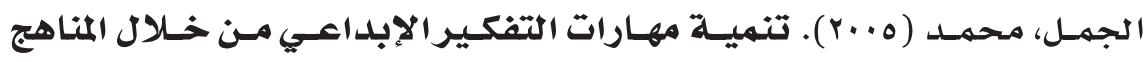

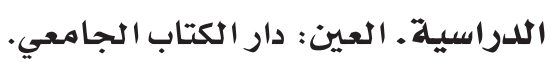

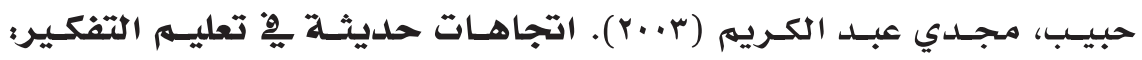
استراتيجيات مستقبلية الألفية الحديثة. القاهرة: دار الفكر العر بي. الخليلي، أمل (0...r). الطفل، ومهارات التفكير، عمان: دار صفاء.

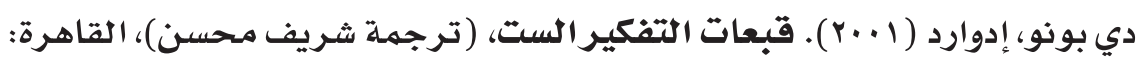
نهضة مصر.

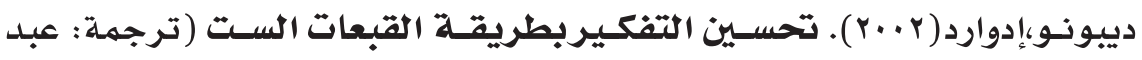

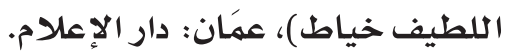

الزيات، فتحي (r . . r). المتفوقون عقلياً ذوو صـعوبات التعلم. القاهرة:دار النشـر لبجامعات.

السرور، ناديا ( .... . . مدخل إلى تربية المتميزين والموهوبين. عمَان: دار الفكر.

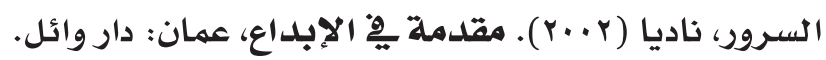

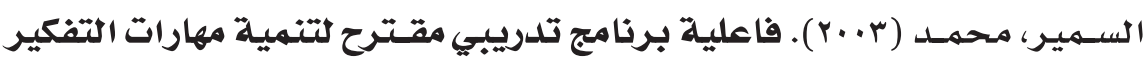

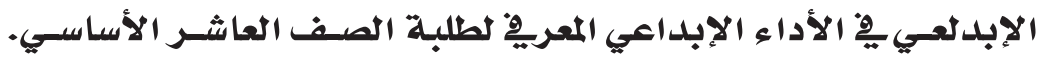
رسالة دكتوراه غير منشورة، جامعة عمان العربية، عمَان، الأردن.

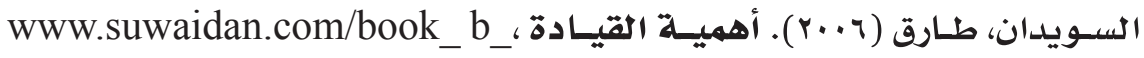
content-2.jsp?id 


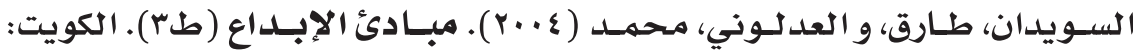

$$
\text { الإبداع الخليجي. }
$$

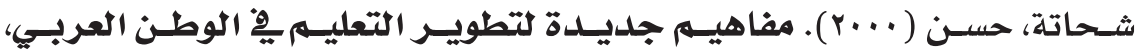
القاهرة: مكتبة الدار العربية للكتاب.

شـرف الديـن، نبيل فضـل (r . . r). فعاليـة فنيات تقوية الذاكرة عـن طريق المعرفة بكيفيـة حدوثها للطلاب الموهوبين ذوي صسعوبات التعلهم بالمرحلة الجامعية،

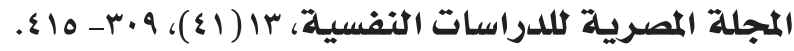

شـريف، السـيد عبد القـادر (0 · ب). إدارة رياض الأطفـال وتطبيقاتها، القاهرة: دار العلوم للتحقيق والطباعة والنشر والتوزيع.

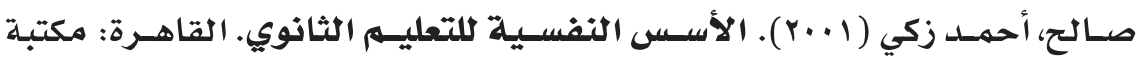

$$
\text { النهضة المهرية. }
$$

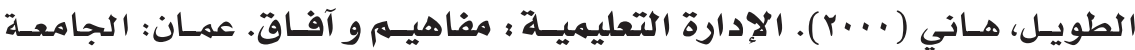

$$
\text { الأردنية. }
$$

عبد العزيز، سعيد (9. . . . تعليه التفكيرومهاراته تدريبات وتطبيقات عملية (طץ)، عمان: دار الثقافة.

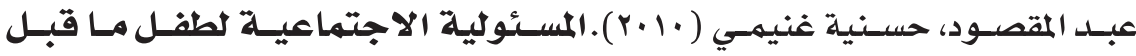
الملدرسة، المجلد الأول، القاهرة: دار الفكر العربي.

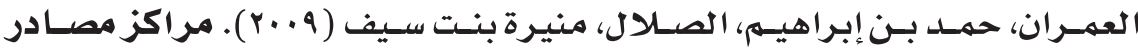
التعلىم، القاهرة: الدار المصرية.

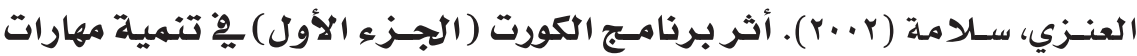
التفكير الإبلداعي ومفهوم الذات لدى طلبة المرحلة المتوسـطة بالكويت، رسـالة ماجسـتير غـير منشـورة، جامعـة الخليـج العربـي، المنامــة، مهلكـة

$$
\text { البحرين. }
$$

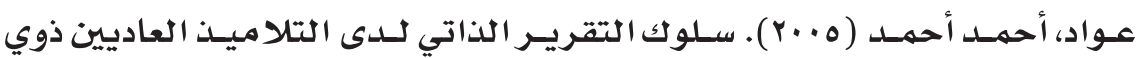

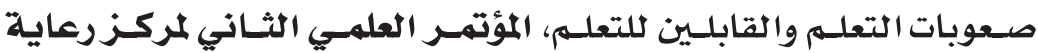
وتنهية الطفولـة : تربية ذوي الاحتياجات الخاصسلة فِ الوطن العربي - الواقع والمستقبل، كلية التربية ، جامعة المنصورة، ص ص |q-^r| . 
عويس، رزان، مرتضى، سلوى (11 +r) . فاعلية طريقة حل المثكلات فِ إكساب أطفال الروضسـة بعض مهارات التفكير دراسـة شـبه تجريبية يْ مدينة دمشـق على

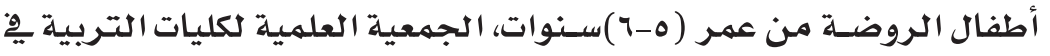

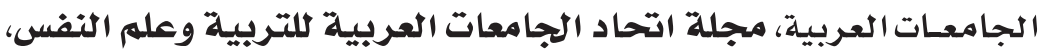

$$
.107-1 \cdot V_{6}(r) \wedge
$$

قطامي، نايفة ( (1. Y). تعليم التفكير للمرحلة الأساسية. . عمان: دار الفكر. قطامي، نايفة (r...r). تعليم التفكير لأطفال.عمان: دار الفكر. متـولي، فكـري لطيـف، القحطـاني، شـتوي مبـارك (10 (r). صـوبات التعلـم لالمبتكرين والموهوبين.

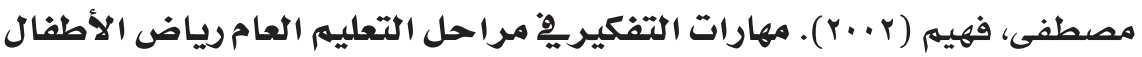
- الابتدائي - الإعدادي - الثانوي رؤية مستقبلية للتعليه مِّه الوطن

$$
\text { العربي. القاهرة: دار الفكر العربي. }
$$

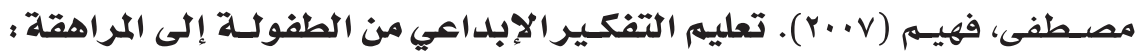
منهج تطبيقي شـامل لتتنميــة التفكيريِّة مراحل التعليـهم العام. القاهرة: دار الفكر العربي.

المناعسي، شمسـان ( • • (Y). دراسـة أثر برنامـج المهارات القيادية على مهارات القيادة

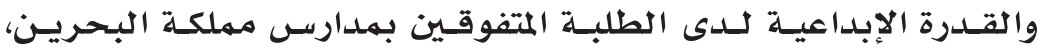

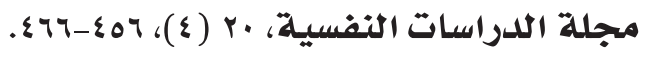

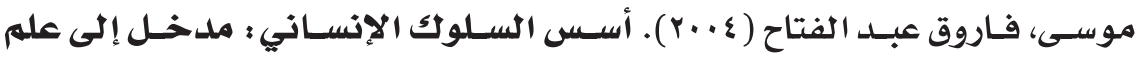
النفس العام. القاهرة: مكتبـة النهضـة المصرية.

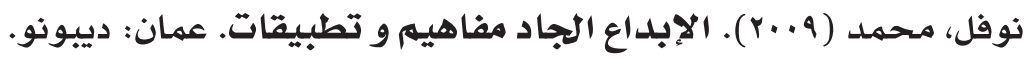
الوهيـب، بـريسة (1999) ). تنميـة مهارات اتخــاذ القـرار لـدى طالبـات المرحلة المتوسطة يٌْ دولة الكويت.جامعة الخليج العربي، المنامة، مهلكة البحرين.

De Bono E. (2004). Six thinking hats (Technique). http://members. Janet, F. \& Kronborg, L. (2000). Leadership development for the gifted and talented. From: www.nexus.Edu.Au/Teach Stud/ gat/far_kro.htm. 
Karnes, F. \& Chauvin, J. (2005). Leadership development program manual (2nd ed.). Great Potentia Press, Inc.: Scottsdale, A

Lesley ,K.(2003).Using edward de bono ,six hats.game to aid critical thinking and reflection in palliative care, International Journal of Palliative Nursing 9(3).

Mary ,P.Jones W.(2004).De Bono six thinking hats method as an approach to ethical dilemmas in pharmacy. American Journal of Pharmaceutical Education ,68(2),Article 54..

Stuart, P. (2003). Leadership styles and problem solving-de bono six hats. Deakin University, Australia. 